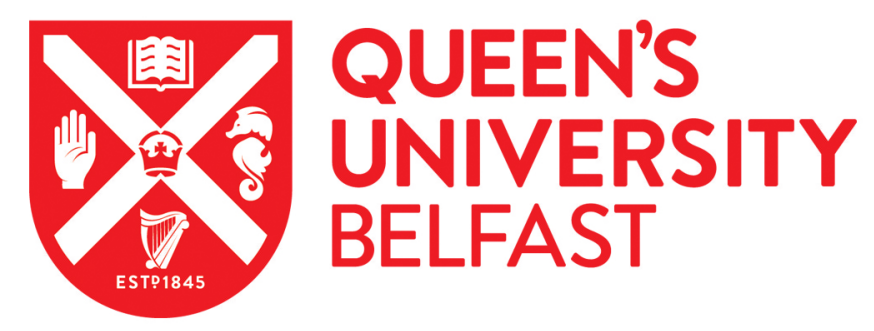

\title{
Strength development of GGBS and fly ash concretes and applicability of fib model code's maturity function - A critical review
}

Vollpracht, A., Soutsos, M., \& Kanavaris, F. (2018). Strength development of GGBS and fly ash concretes and applicability of fib model code's maturity function - A critical review. Construction and Building Materials, 162, 830-846. https://doi.org/10.1016/j.conbuildmat.2017.12.054

Published in:

Construction and Building Materials

Document Version:

Peer reviewed version

Queen's University Belfast - Research Portal:

Link to publication record in Queen's University Belfast Research Portal

\section{Publisher rights}

Copyright 2017 Elsevier.

This manuscript is distributed under a Creative Commons Attribution-NonCommercial-NoDerivs License

(https://creativecommons.org/licenses/by-nc-nd/4.0/), which permits distribution and reproduction for non-commercial purposes, provided the author and source are cited.

\section{General rights}

Copyright for the publications made accessible via the Queen's University Belfast Research Portal is retained by the author(s) and / or other copyright owners and it is a condition of accessing these publications that users recognise and abide by the legal requirements associated with these rights.

Take down policy

The Research Portal is Queen's institutional repository that provides access to Queen's research output. Every effort has been made to ensure that content in the Research Portal does not infringe any person's rights, or applicable UK laws. If you discover content in the Research Portal that you believe breaches copyright or violates any law, please contact openaccess@qub.ac.uk. 


\title{
Strength development of GGBS and fly ash concretes and applicability of fib model code's maturity function - a critical review
}

\author{
Anya Vollpracht ${ }^{1, *}$, Marios Soutsos ${ }^{2}$, and Fragkoulis Kanavaris ${ }^{2}$. \\ ${ }^{1}$ Institute of Building Materials Research, RWTH Aachen University, Aachen, Germany \\ ${ }^{2}$ School of Natural and Built Environment, Queen's University Belfast, Belfast BT9 5AG, UK. \\ * corresponding author
}

\section{Abstract}

This paper is the joint work of working group 4 of the RILEM TC 238-SCM and the fib Task Group 4.6. It was the aim of this literature study to quantify the effect of ground granulated blast furnace slag (GGBS) and silicious fly ash (sFA) on strength development of concrete. For the strength development the approach of the fib Model Code was chosen, which is based on an e-function that can be adapted to the strength development of an individual binder by selecting the so-called s-value based on the strength class of the Portland cement used. No guidance is provided for s-values for supplementary cementitious materials (SCMs). In order to determine the s-values for mixes with SCMs, a database was set up with results of material testing from literature. A relationship between $s$-values and $w / b$ plus $\mathrm{SCM} / \mathrm{b}$ ratios has been determined. This has been tested on laboratory cast specimens with 50 and $30 \%$ cement replacement with GGBS and FA respectively. These were cured at $20^{\circ} \mathrm{C}$. The s-values from this relationship were compared to those obtained from regression analysis and they were found to be satisfactory. This increased confidence in their use for predicting the strength development of other curing regimes, i.e. adiabatically cured concrete cubes, using the maturity function in the fib Model Code. Predictions of the effect of curing temperature, i.e. the adiabatic temperature history, on the strength development were again satisfactory. These were not significantly affected by the fib model code's use of one value of "apparent" activation energy.

Key words: strength development, maturity, fly ash, ground granulated blast furnace slag 


\section{Introduction}

There has been a significant change in the types of cements used in the last decade. Whilst before the norm was a neat Portland cement, nowadays referred to as CEM I, environmental considerations, i.e. carbon footprint, has led to CEM II and CEM III cements becoming popular. Many of these cements contain fly ash (FA) or ground granulated blast-furnace slag (GGBS) which alter the compressive strength-time relationship. The designers usually use the 28-day characteristic compressive strength for structural calculations. Whilst SCMs may be used to design concretes of equivalent 28-day strength as neat Portland cement (CEM I) their early age strength development is not only significantly different but it is also affected to a greater extent by curing temperature.

High early age strength, e.g. $15 \mathrm{~N} / \mathrm{mm}^{2}$ at 16 hours, are needed by precast concrete factories for lifting operations in order to maintain their daily production of structural and non-structural elements. The factors affecting strength at early ages must therefore be considered. These factors include the composition of the concrete mixture, such as cement type and SCM addition and the use of retarding or accelerating admixtures. The strength development of the concrete is also influenced by temperature. Strength gain is more rapid at higher temperatures and slower at lower temperatures and if the temperature is too low then strength gain will cease altogether.

The need to understand and quantify the effect of temperature on the early age strength development of concrete mixes has been recognised for a long time. This was mainly for:

(a) determining elevated curing temperature needed to achieve the required early strengths for safely lifting precast concrete elements as early as sixteen hours after casting [1] and

(b) predicting the in-situ strengths especially during cold weather concreting, to allow stripping of formwork and removal of props without a collapse like the one that occurred in Willow Island in 1978 which resulted in 51 deaths [2, 3]. 
This can be achieved with maturity methods which account for the combined effect of binder composition and temperature on the strength development of concrete [4 - 9].

\section{Strength development}

\subsection{General}

The replacement of Portland cement by GGBS or fly ash usually results in a reduced early strength, often coupled with an increase in late strength. According to the fib Model code [10] the strength of concrete at a certain point in time can be calculated from the strength at 28 days according to the following equation:

$\mathrm{f}_{\mathrm{cm}}(\mathrm{t})=\beta_{\mathrm{cc}}(\mathrm{t}) \cdot \mathrm{f}_{\mathrm{cm}, 28 \mathrm{~d}} \quad$ with $\quad \beta c c(t)=e^{s \cdot\left(1-\sqrt{\frac{28 d}{t}}\right)}$

where

$f_{c m}(t)$ is the mean compressive strength in $N / \mathrm{mm}^{2}$ at an age $t$ in days,

$\mathrm{f}_{\mathrm{cm}, 28 \mathrm{~d}}$ is the average compressive strength in $\mathrm{N} / \mathrm{mm}^{2}$ at an age of 28 days,

$\beta_{c c}(t)$ is a function to describe the strength development with time,

$t$ is the concrete age in days,

$s$ is a coefficient, which depends on the strength class of the cement.

The model code gives the following benchmarks for the different strength classes defined in the European standard EN 197-1:

$32.5 \mathrm{~N}$ :

$s=0.38$

$32.5 \mathrm{R}$ and $42.5 \mathrm{~N}$ :

$s=0.25$

42.5 R, 52.5 N and 52.5 R: $\quad \mathrm{s}=0.20$

These values are valid for $20^{\circ} \mathrm{C}$ and water storage.

For concretes with high GGBS or fly ash contents strength development is slower, which leads to higher s-values. In order to quantify that effect, data on strength development of concretes with GGBS and/or fly ash were collected from research reports and literature [11 78] and internal reports of material testing at the Institute of Building Materials Research, RWTH Aachen University, (ibac) [65]. For comparison concretes with CEM I of different strength classes were also included in this study. The compressive strength of each concrete 
was tested at least at three points in time, always including 28 days. The average number of testing ages was 4.5. The s-value of every binder was fitted using equation (1). Since all experimental data show some scatter, the measured 28 day strength was not taken as a fixed value. Instead a fitting was carried out, allowing a variation of the $28 \mathrm{~d}$ strength in the range of \pm half a strength class compared to the measured value in order to get the most appropriate s-value for the strength development. Fig. 1 shows two examples of the fitting, a typical and a bad example. The bad example shows that in a few cases the experimental data could not be described adequately with equation (1). 18 out of 1017 data sets were not considered, because the average discrepancy between measured and calculated strength was more than $2.0 \mathrm{~N} / \mathrm{mm}^{2}$. Results for very early ages $(<24 \mathrm{~h})$ should not be considered in the fitting of the s-value because high discrepancies at later ages were found in this study. That means on the other hand that the strength at $\mathrm{t}<24 \mathrm{~h}$ cannot be predicted by equation (1).

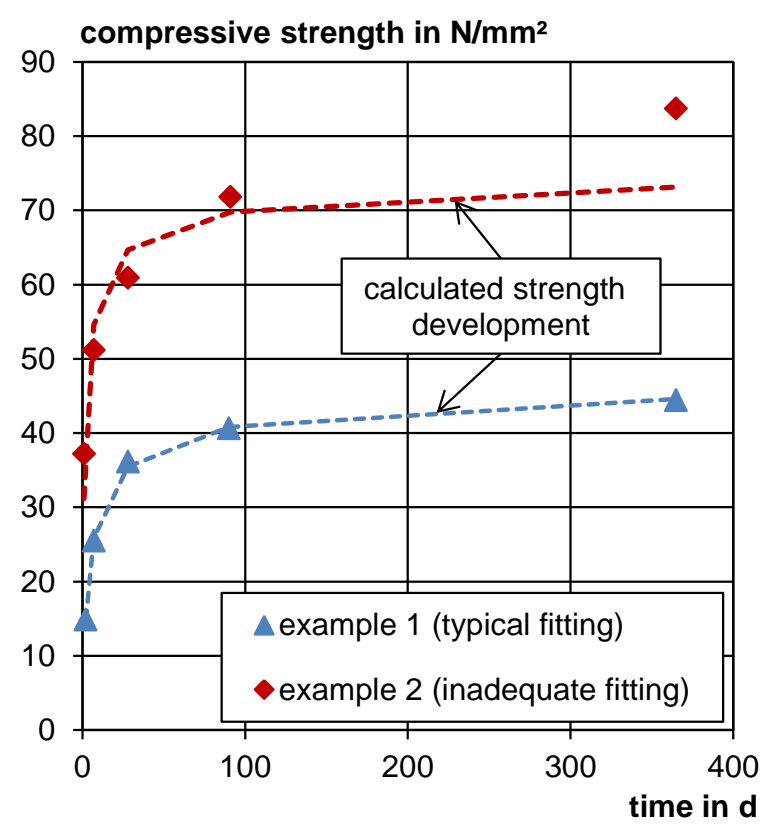

Fig. 1: Fitting of experimental data on strength development (example 1: B13, [25], example 2: no. 12, [15]); dots: experimental data, dotted lines: fitted curves

The database includes only concrete samples with a minimum dimension of $100 \mathrm{~mm}$. The curing temperature was $20 \pm 3{ }^{\circ} \mathrm{C}$. The humidity storage conditions of the samples varied. Some samples were stored under water or in a fog room and others were stored under water for 7 days and at $65 \%$ relative humidity afterwards. An overview of the available data is given in the Annex, Table A 1 to Table A 4. The tables give information on binder composition, strength class of the cement, the water/cement ratios (w/c) and the storage conditions. 
Quite often the strength class of the cements is not specified in non-European literature, but in many cases results of mortar compressive strength tested according to ASTM C 109 are included in the papers. These results were used to classify the cements according to EN 197-1 (assuming a size factor of $f_{c m}, 51 \mathrm{~mm} / f_{c m}, 40 \mathrm{~mm}=0.95$ ). Most of these cements were assigned to strength class $32.5 \mathrm{R}$ or $42.5 \mathrm{~N}$.

\subsection{Influence of curing conditions, binder composition and $\mathrm{w} / \mathrm{b}$ ratio}

As mentioned above all concretes were cured at $20 \pm 3{ }^{\circ} \mathrm{C}$ but at different humidity conditions. The humidity may influence the subsequent hardening of concrete. Exemplarily Fig. 2 shows the s-values of concretes with different binders and similar w/b-ratios prepared with cements of strength class $32.5 \mathrm{R}$. The s-values show a large scatter, but nevertheless it can be seen that there is no systematic difference between 7 days of curing and water storage. There are a few results with only one or two days of curing in the data base and they show lower s-values indicating that the hydration of the cement is affected and the subsequent hardening is lower. Fig. 2 shows that for concrete samples with a minimum sample size of $100 \mathrm{~mm} 7$ days of curing are sufficient to reach good subsequent hardening. For the further evaluation of the data no distinction was made between the curing conditions C7, W and FR.

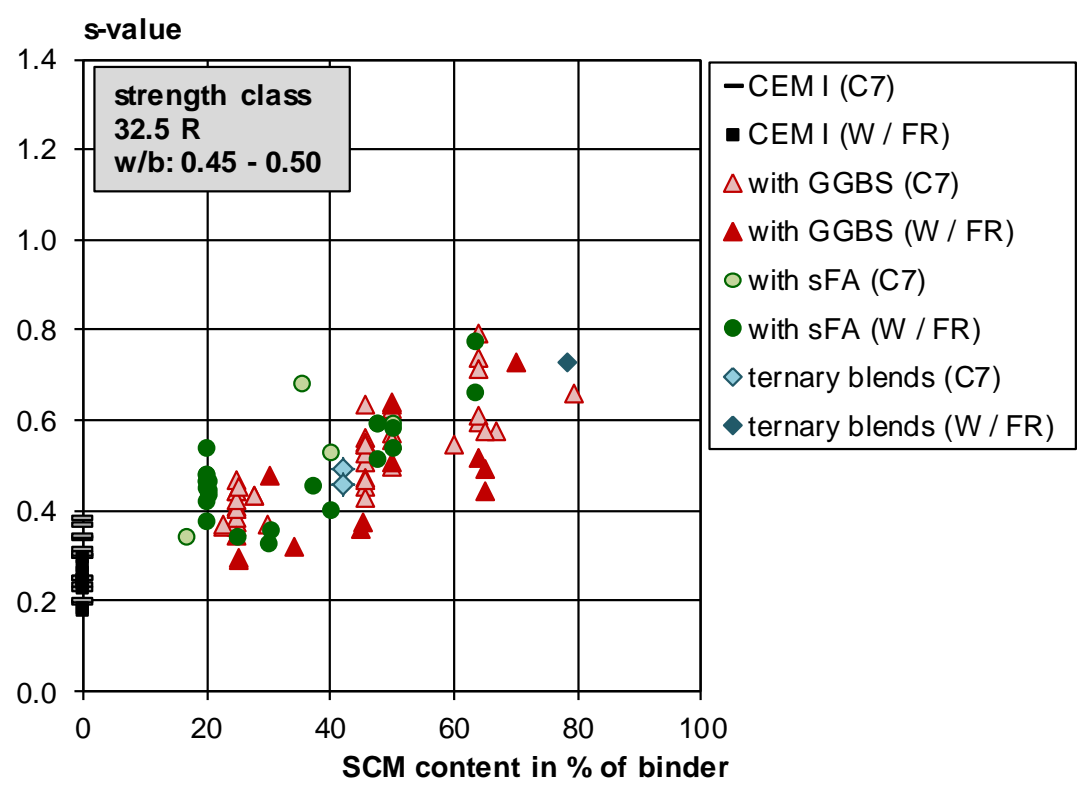

Fig. 2: Influence of curing conditions on the s-values of concretes with different binders (C7: 7 days of water curing and storage at $65 \%$ r. h. afterwards, W: water storage, FR: fog room); data from [16, 17, 20, 21, 24 - 26, 30, 31, 45, 46, 47 - 49, 52, 55, 64, 65, 78]

Fig. 2 shows that s-values increase with increasing SCM content of the binder. 
The influence of the strength class of the cement is shown in Fig. 3 exemplarily for Portland cement concrete and concrete with GGBS in a w/b range of 0.45 to 0.50 . Cements with higher strength classes tend to show lower s-values as it was expected from [10].For strength class $32.5 \mathrm{~N}$ there was only data available for CEM III and CEM II/B-S. The figure shows that the s-values of concretes with strength class $32.5 \mathrm{~N}$ cements do not exceed the values of class $32.5 \mathrm{R}$. Therefore it was decided to generate only two groups of strength classes:

- $\quad 32.5 \mathrm{~N}, 32.5 \mathrm{R}$ and $42.5 \mathrm{~N}$

- $\quad 42.5 \mathrm{R}, 52.5 \mathrm{~N}$ and $52.5 \mathrm{R}$

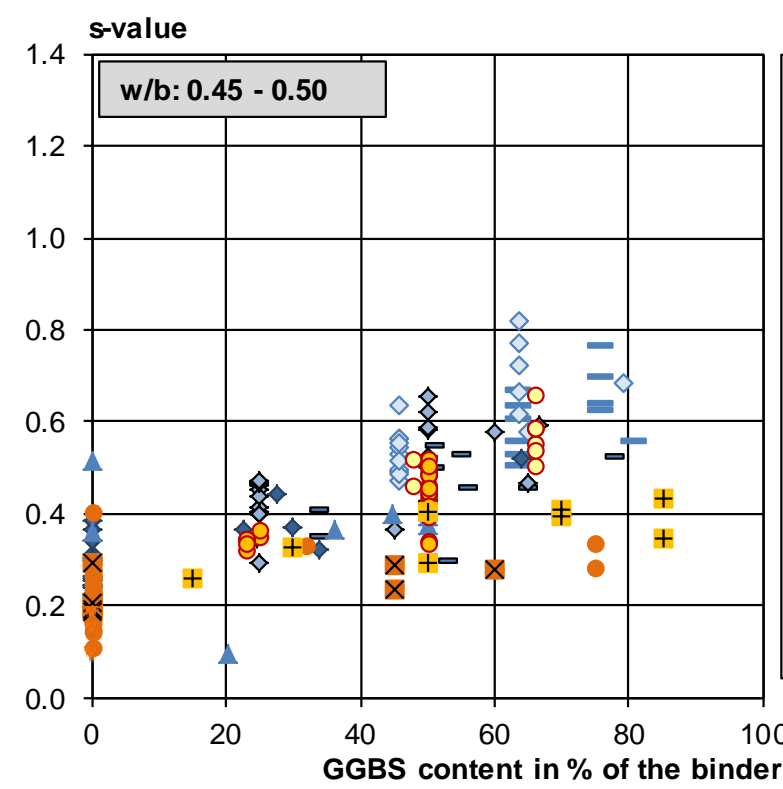

cements of strength class $32.5 \mathrm{~N}$

- combination s of CEM II/B-S or CEM III $32.5 \mathrm{~N}$ with GGBS

$\checkmark$ cements of strength class $32.5 \mathrm{R}$

$\diamond$ combinations of CEM I 32.5 R with GGBS

$\diamond$ combinations of CEM II/B-S or CEM III $32.5 \mathrm{R}$ with GGBS

$\triangle$ cements of strength class $42.5 \mathrm{~N}$

- cements of strength class $42.5 \mathrm{R}$

O combinations of CEM I 42.5 R with GGBS

o combinations of CEM II/B-S or CEM III $42.5 \mathrm{R}$ with GGBS

$x$ cements of strength class $52.5 \mathrm{~N}$

+ combinations of CEM I $52.5 \mathrm{~N}$ with GGBS

v cements of strength class $52.5 \mathrm{R}$

Fig. 3: Influence of the strength class of the cement on the s-values of concrete; data from $[17,21,24-26,41,65,78]$

The influence of the type of binder is shown in Fig. 4 exemplarily for binders with GGBS and for Portland cements. Concretes made of CEM I and GGBS are in the same range as concretes with binders that contain GGBS in the cement. The use of blast furnace slag cements tends to result in slightly lower s-values, because the early age strength is usually optimised by the cement producer. But since almost all CEM III/A results are still within the scatter of CEM I with GGBS, it was decided not to draw a distinction between GGBS used in cement or as an additive to concrete. 


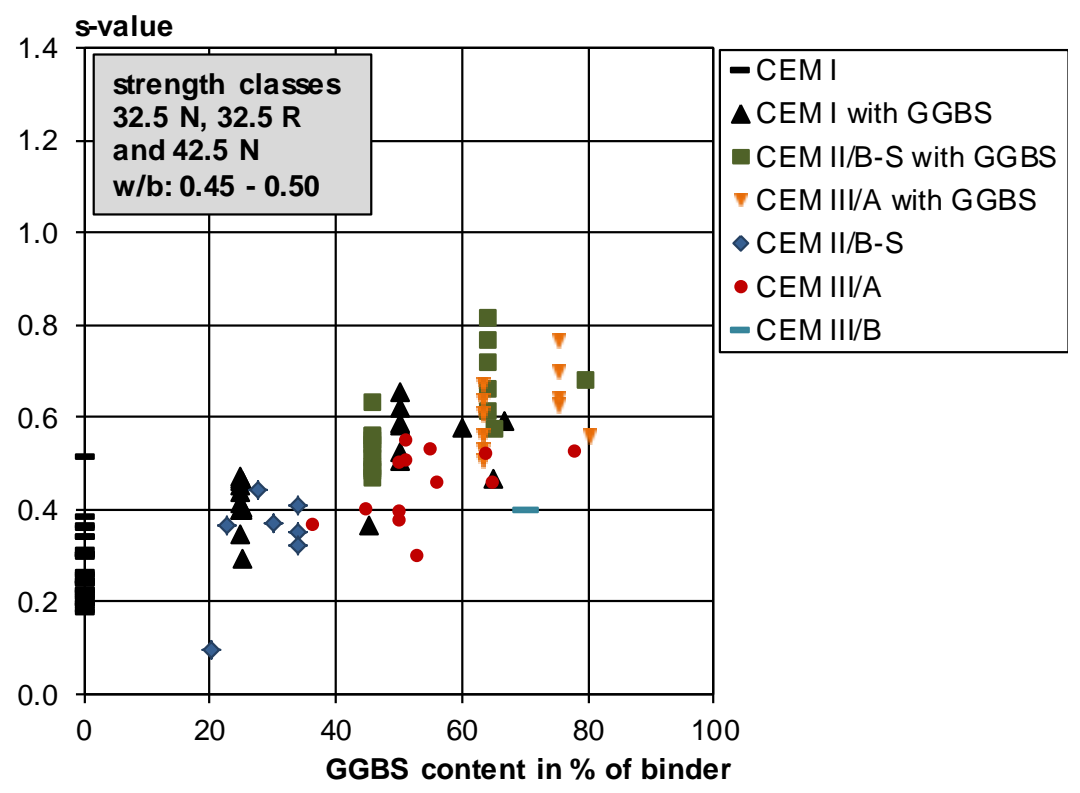

Fig. 4: Influence of binder composition and strength class of the cement on the s-values of concrete $\left({ }^{*}\right.$ : strength class was not given in the paper, but could be determined from mortar compressive strength); data from [17, 21, 24 - 26, 41, 65, 78]

The influence of the water/binder ratio is shown in Fig. 5 for Portland cement. The s-value increases with increasing $w / b$ ratio, but the scatter is quite high even within one strength class.

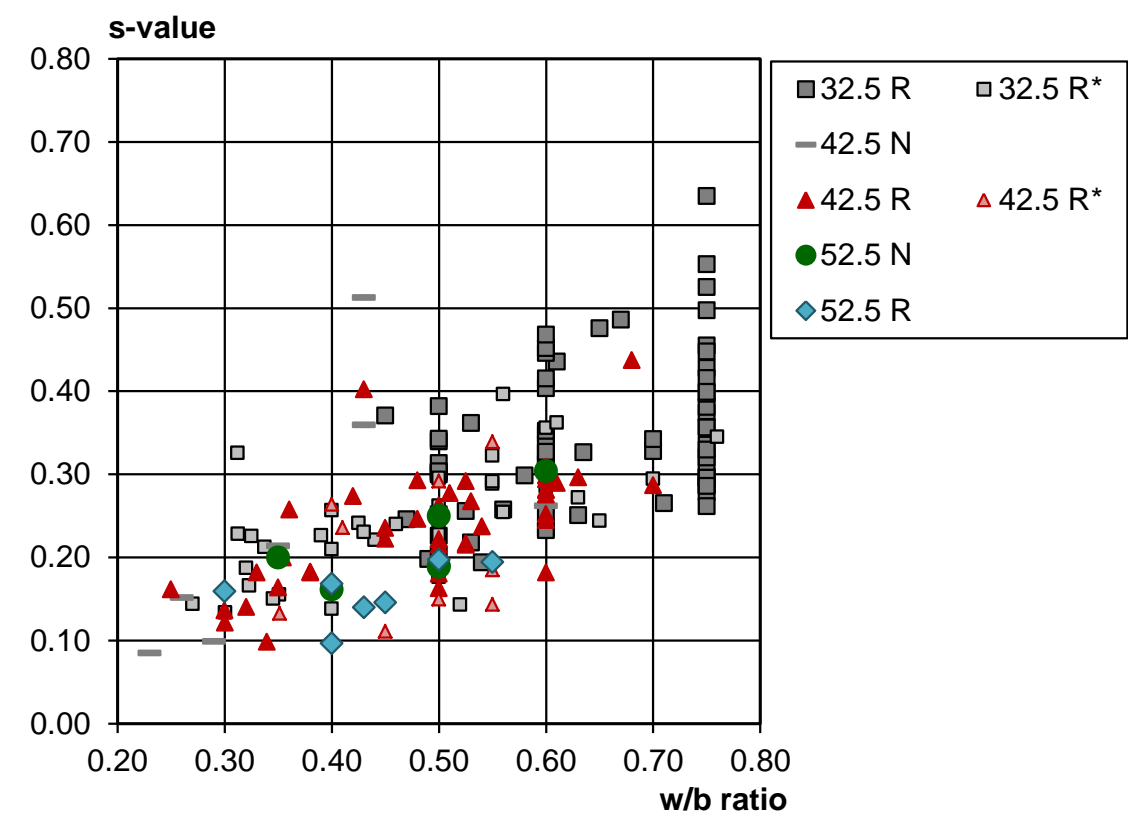

Fig. 5: Influence of the water/binder ratio on the s-values of concrete ( ${ }^{*}$ : strength class was not given in the paper, but could be determined from mortar compressive strength); data from $[15$ - 17, 20 - 25, 27, 30 - 32, 34, 36 - 41, 43 - 50, 52 - 62, 64, 65 - 68, 72 74, 76- 78]

In the following figures, the data was arranged according to the $w / b$ ratio as follows: 
$-\quad 0.25-0.39$

$-\quad 0.40-0.54$

$-\quad 0.55-0.69$

$-\quad \geq 0.70$

An average s-value was calculated for binders that were tested with several $\mathrm{w} / \mathrm{b}$ ratios within the same $\mathrm{w} / \mathrm{b}$ range.

Fig. 6 and Fig. 7 show the results of the statistical evaluation of the s-values. The available data was summarised according to the $\mathrm{w} / \mathrm{b}$ ratio and the strength class of the cement and plotted against the SCM content. A best fit line was calculated for all data points as well as a $90 \%$ range. The figures show that the scatter is high even for pure Portland cement concrete. The s-values given in the fib Model Code (see paragraph 2.1) do not consider the influence of $w / b$-ratio. For pure Portland cement concrete made with cements of strength class $32.5 \mathrm{R}$ or $42.5 \mathrm{~N}$ the s-value of 0.25 is appropriate for a rough estimation, but only in a w/b-range of 0.40 to 0.55 . For $42.5 \mathrm{R}$ and $52.5 \mathrm{~N}$ the s-value of 0.20 fits more or less for a $\mathrm{w} / \mathrm{b}$-range of 0.40 to 0.50 . For $52.5 \mathrm{R}$ the $\mathrm{s}$-values are lower than predicted by the Model Code. For concretes with SCM the s-values form the Model Code are usually too low. 

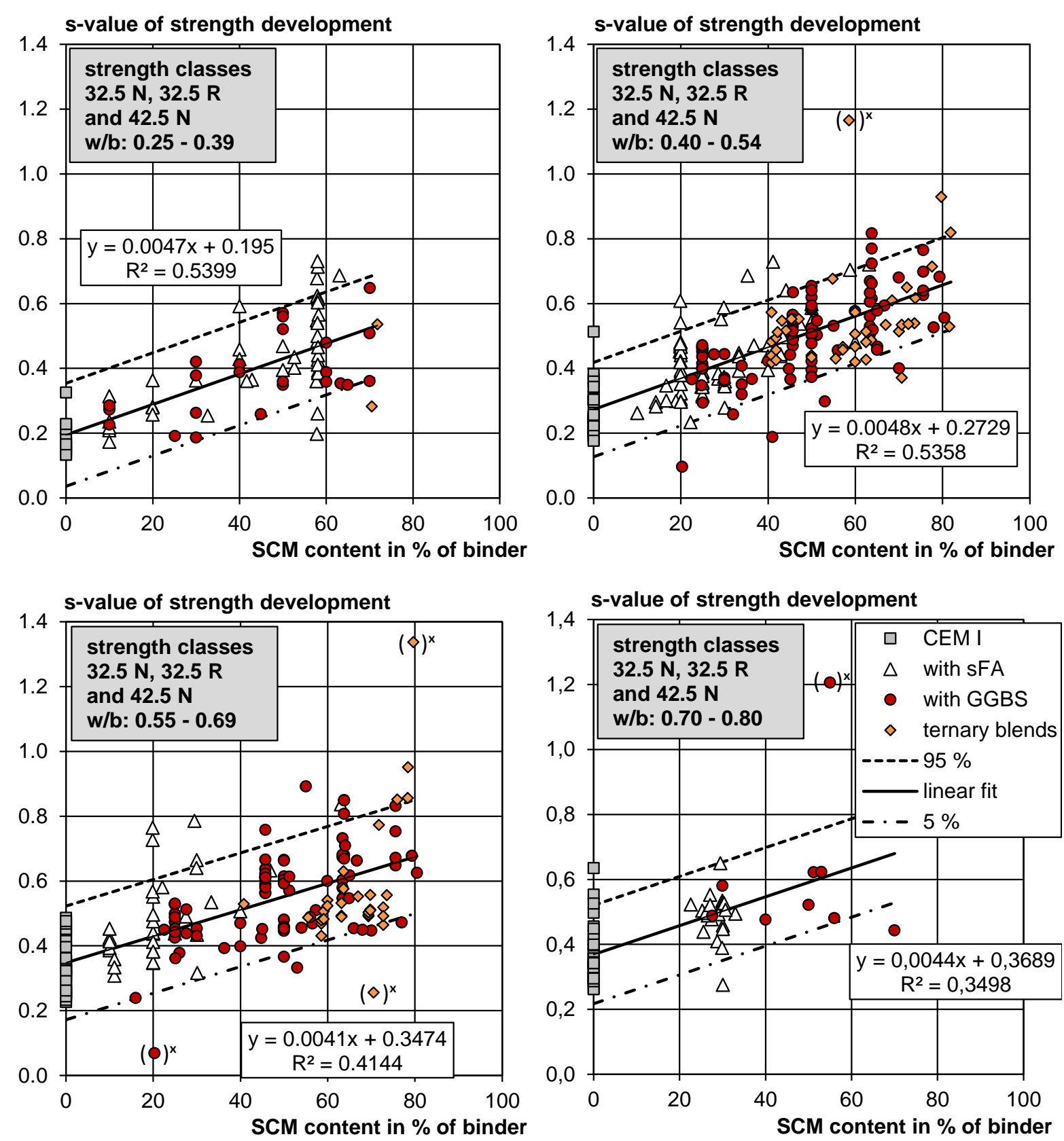

Fig. 6: Statistical evaluation of the s-values of concretes with cements of the lower strength classes in dependence of $w / b$ ratio and SCM content ${ }^{*}$ : outliers, identified with the outlier test of Dixon 

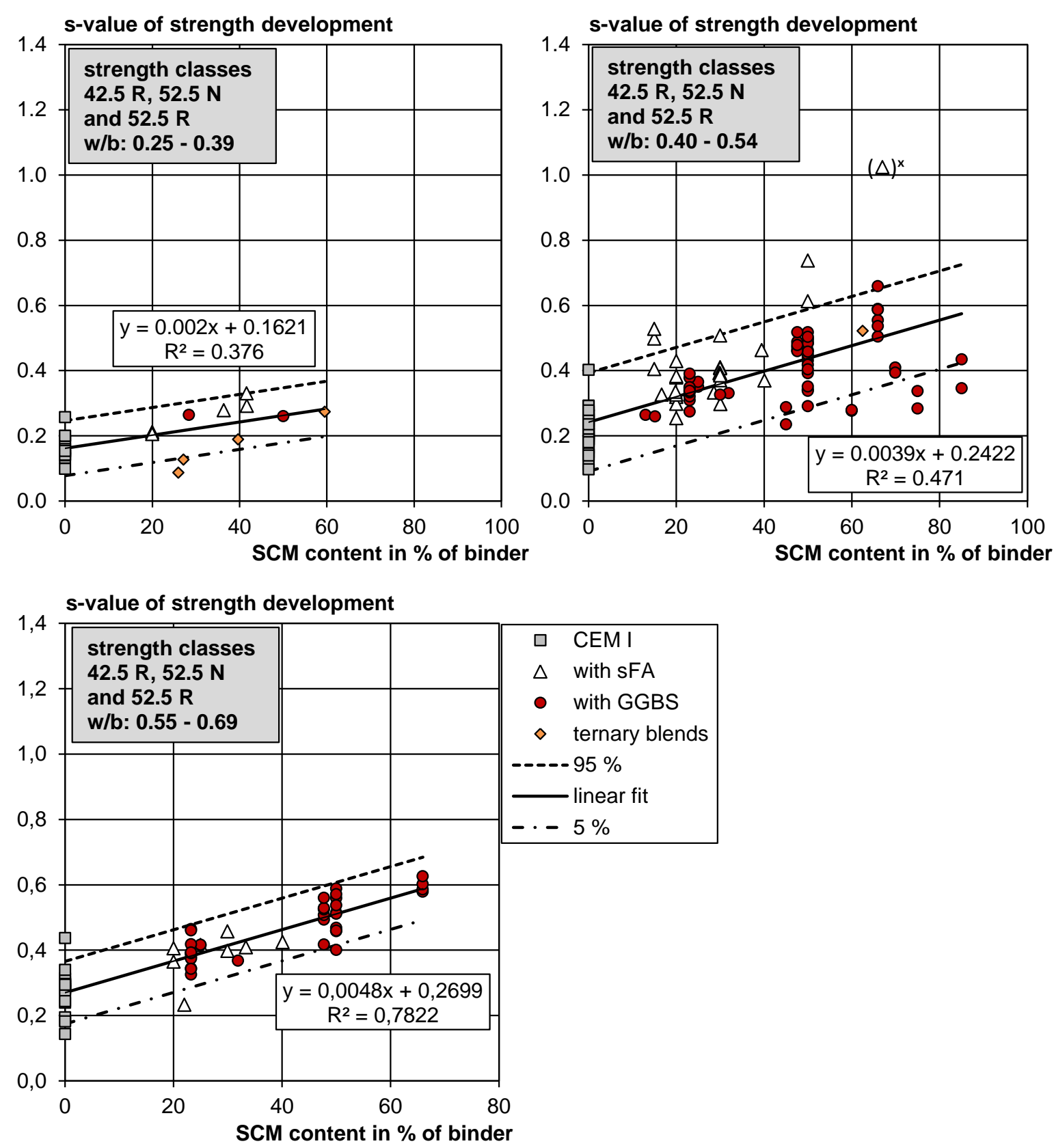

Fig. 7: Statistical evaluation of the s-values of concretes with cements of the higher strength classes in dependence of $\mathrm{w} / \mathrm{b}$ ratio and SCM content $\mathrm{x}$ : outliers, identified with the outlier test of Dixon 


\subsection{Prognosis of strength development with the s-value}

Fig. 6 and Fig. 7 show that the s-value depends on w/b ratio and SCM content. The correlations seem to be linear. A multiple linear regression analysis was carried out to quantify the influence of the two factors leading to equation (2). The implementation of a constant summand $c_{3}$ does not improve the fitting. Therefore $c_{3}$ was neglected to keep the equation as simple as possible.

$\mathrm{s}=\mathrm{c}_{1} \cdot \mathrm{w} / \mathrm{b}+\mathrm{c}_{2} \cdot \mathrm{scm} / \mathrm{b}$

where

$\mathrm{w} / \mathrm{b}$ is the free water to binder ratio (non-dimensional),

$\mathrm{scm} / \mathrm{b}$ is the mass proportion of SCM in the binder (non-dimensional),

$\mathrm{C}_{1}, \mathrm{C}_{2}$ are coefficients depending on the strength class of the cement.

The factors $c_{1}$ and $c_{2}$ were fitted with the least square method using all the available data (606 concretes for the lower strength classes and 255 concretes for the higher strength classes). The following results were obtained:

$32.5 \mathrm{~N}, 32.5 \mathrm{R}, 42.5 \mathrm{~N}: \mathrm{c}_{1}=0.528, \mathrm{c}_{2}=0.527$

42.5 R, 52.5 N, 52.5 R: $c_{1}=0.481, c_{2}=0.441$

The correlation between the s-value determined according to paragraph 2.1 and the s-value calculated according to Eq. (2) is shown in Fig. 8. The correlation leads to a $R^{2}$ of 0.466 , which is rather low. It has to be assessed how this is reflected in the prognosis of strength development. 


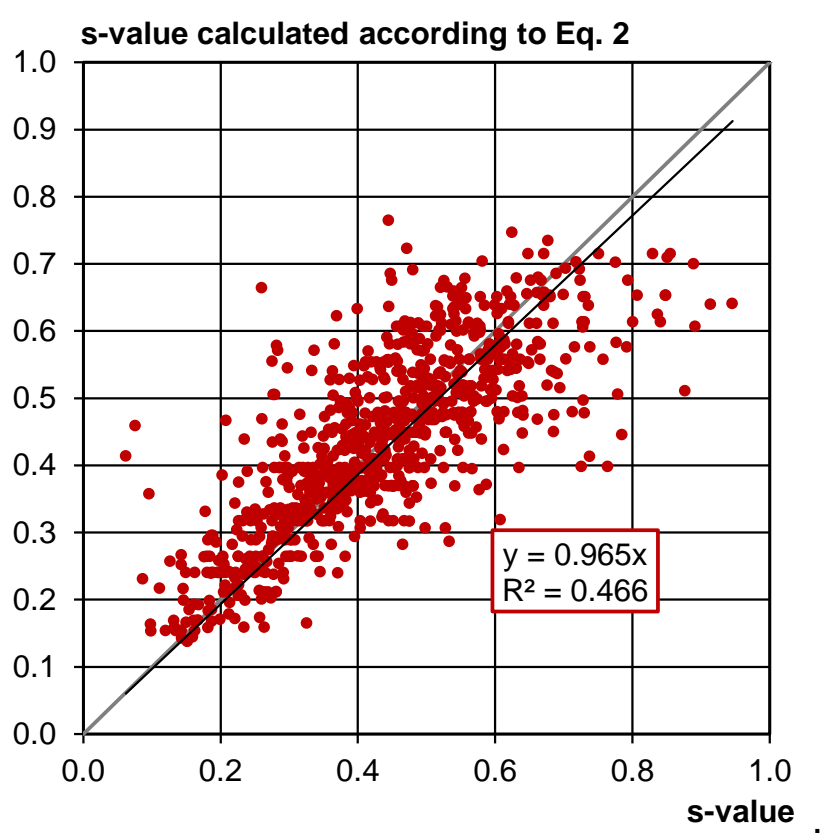

Fig. 8: Evaluation of the accuracy of Eq. (2) for the calculation of the s-value

Another option to determine the s-value of a specific concrete is an individual calculation based on early age strength and the $28 d$ strength by transforming Eq. (1) to Eq. (3):

$S=\frac{\ln \left(f_{c m}(\mathrm{t})\right)-\ln \left(f_{c m, 28 d}\right)}{1-\sqrt{\frac{28 d}{t}}}$

where

$t$ is the concrete age ( 1 to 3 days)

This individual fitting is supposed to give a good approximation of the strength development.

Both approaches were used to calculate the s-value and predict the compressive strength at $7 \mathrm{~d}, 56 \mathrm{~d}$ and $91 \mathrm{~d}$ using Eq. (1). Fig. 9 shows the correlation of these predicted values and the measured compressive strength. A statistical evaluation of the errors $\left(\Delta f_{c m}=f_{c m}\right.$,measured $\left.f_{\mathrm{cm}, \text { predicted }}\right)$ gave the following standard deviations:

$7 \mathrm{~d}$ : $\quad$ s calculated according to Eq. (2): $\quad 2.99 \mathrm{~N} / \mathrm{mm}^{2}$ s calculated with early age strength (Eq. (3)):2.22 N/mm²

$56 \mathrm{~d}$ : s calculated according to Eq. (2):

s calculated with early age strength (Eq. (3)):2.88 N/mm² 
$91 \mathrm{~d}$ : s calculated according to Eq. (2):

$\mathrm{s}$ calculated with early age strength (Eq. (3)):4.18 N/mm²

predicted compressive strength in $\mathbf{N} / \mathbf{m m}^{2}$
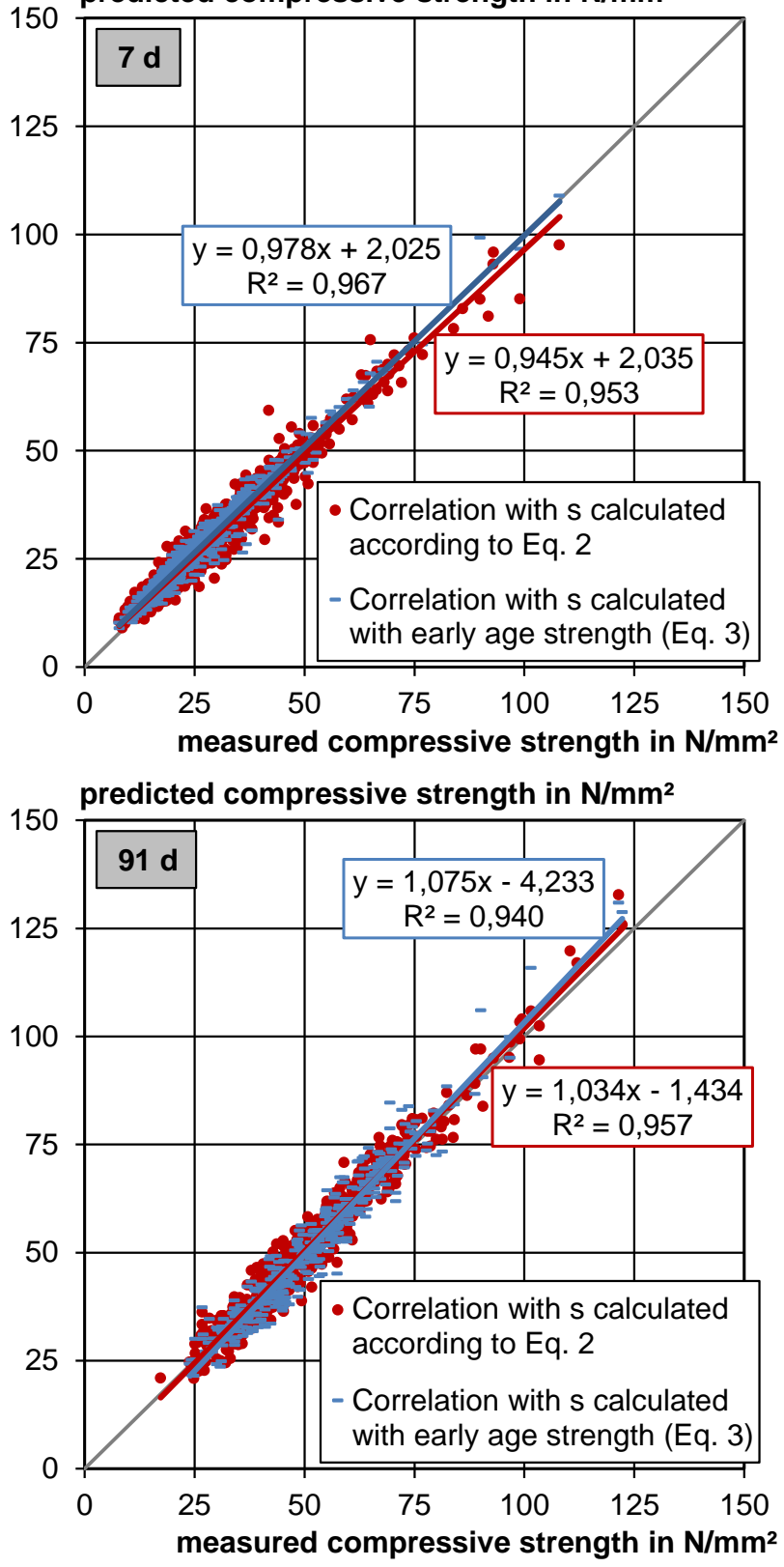

predicted compressive strength in $\mathrm{N} / \mathrm{mm}^{2}$

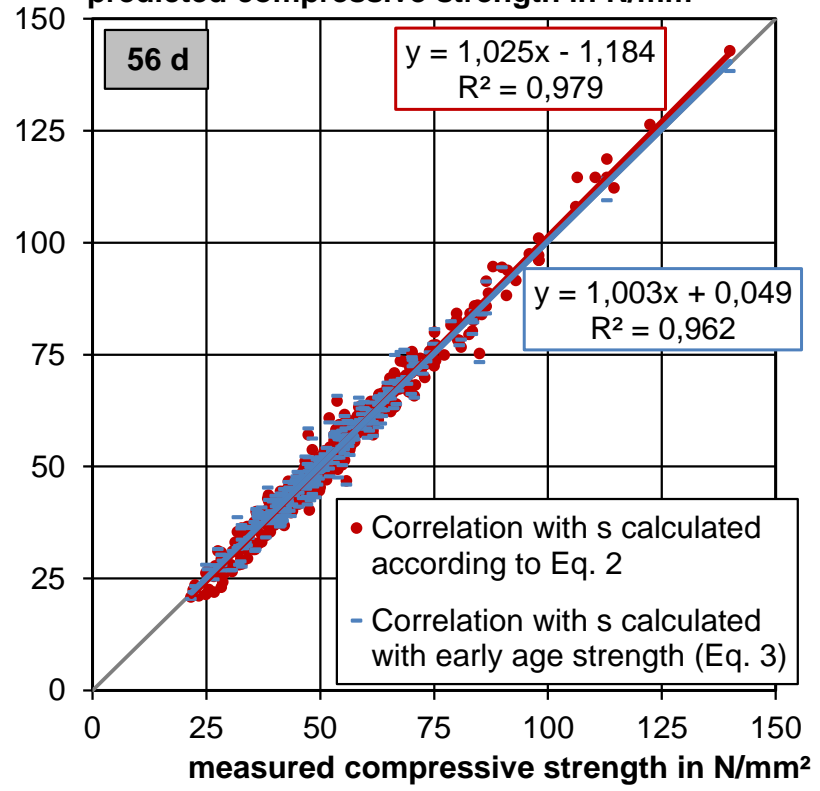

Fig. 9: Correlation between predicted and measured compressive strength at different concrete ages ( $7 \mathrm{~d}, 56 \mathrm{~d}$ and $91 \mathrm{~d}$ )

Considering the typical standard deviation of compressive strength testing, which is about $4 \mathrm{~N} / \mathrm{mm}^{2}$, both approaches are quite reliable. For the prediction of the strength between 3 
and 28 days the calculation based on early age strength is a bit more precise. Therefore it is recommended to use Eq. (3) to calculate curing times.

For later ages the accuracy of the prediction with Eq. (3) decreases, because the s-value was calculated based on early age strength. Some countries, like Germany or Japan, allow higher assessment ages for concretes with high SCM contents for special applications like mass concrete. Eq. (2) can be used to predict the compressive strength at these later ages (usually 56 or 91 days).

\section{Maturity function}

All maturity functions require first the determination of a strength-time relationship. The fib model code uses Eq. (1). The applicability of this relationship for concrete mixes with SCMs has been discussed above. It has been suggested that more appropriate values for the $s$ parameters for mixes with SCMs can be obtained from Eq. (2). This has been investigated for Portland cement (PC) concretes of 30 and $50 \mathrm{MPa}$ 28-day cube compressive strength and results are reported in this section. Mixes with $30 \%$ cement replacement with fly ash (FA) and with $50 \%$ cement replacement with ground granulated blast furnace slag (GGBS) have also been investigated.

\subsection{Materials and experimental methods}

\subsubsection{Materials}

Portland cement (PC) CEM I 52.5 N, conforming to the requirements of BS EN 197-1:2000 and having a 28-day compressive strength of $57 \mathrm{MPa}$ (tested according to the method described in BS EN 196-1-2005), was supplied in bags by British Lime Industries. PC was partially replaced with ground granulated blast furnace slag (GGBS) and fly ash (FA) conforming to BS EN 15167-1:2006 and BSEN 450-1:2005, respectively. GGBS was supplied in bags by the Appleby Group whereas FA was supplied in sealed plastic buckets by Fiddlers Ferry, a coal-fired electricity-generating station, in Warrington, UK. The chemical composition of PC, GGBS and FA are shown in Table 1. 
Table 1: Chemical composition of PC, GGBS and FA

\begin{tabular}{|c|c|c|c|}
\hline \multirow{2}{*}{ chemical constituent } & PC & GGBS & $\mathrm{FA}$ \\
\hline & \multicolumn{3}{|c|}{ w.-\% (dried samples) } \\
\hline $\mathrm{SiO}_{2}$ & 20.11 & 35.35 & 48 \\
\hline $\mathrm{Al}_{2} \mathrm{O}_{3}$ & 5.16 & 14 & 27 \\
\hline $\mathrm{Fe}_{2} \mathrm{O}_{3}$ & 3.14 & 0.36 & 9 \\
\hline $\mathrm{CaO}$ & 65.49 & 41.41 & 3.3 \\
\hline $\mathrm{MgO}$ & 0.8 & 7.45 & 2 \\
\hline $\mathrm{SO}_{3}$ & 3.22 & 0.1 & 0.6 \\
\hline $\mathrm{K}_{2} \mathrm{O}$ & 0.59 & - & 3.8 \\
\hline $\mathrm{Na}_{2} \mathrm{O}$ & 0.13 & - & 1.2 \\
\hline $\mathrm{CaCO}_{3}$ & 4.47 & - & - \\
\hline Equiv. Alks $\mathrm{Na}_{2} \mathrm{Oe}$ & 0.52 & - & - \\
\hline Free Lime & 1.79 & - & - \\
\hline Chloride & 0.0071 & - & - \\
\hline LOI & 2.8 & 0.31 & 4.9 \\
\hline
\end{tabular}

The coarse aggregate initially used was $5-20 \mathrm{~mm}$ uncrushed round gravel from the Fagl Lane quarry, which is located in Wales. Its specific density and water absorption were $2.64 \mathrm{~g} / \mathrm{cm}^{3}$ and $1.7 \%$, respectively. The fine aggregate used was well graded fine aggregate also obtained from the Fagl Lane quarry having a specific density of $2.60 \mathrm{~g} / \mathrm{cm}^{3}$ and a water absorption of $2.6 \%$. The combined grading curve for the Fagl Lane gravel and sand is shown in Fig. 10.

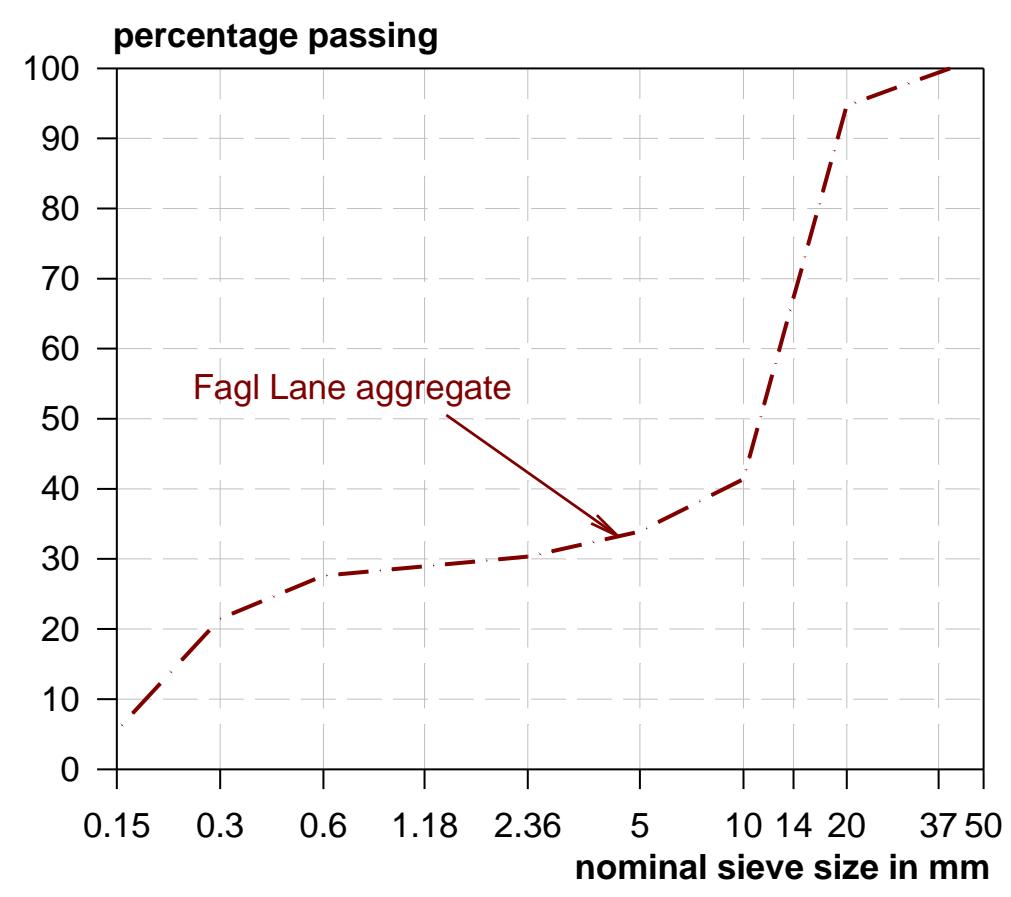


Fig. 10: Combined grading for coarse and fine aggregate

\subsubsection{Concrete mixes investigated}

The concrete mixes investigated aimed to have 28-day compressive strengths of 30 and $50 \mathrm{~N} / \mathrm{mm}^{2}$. The neat Portland cement mixes were named PC30 and PC50. FA30 and FA50 were mixes with $30 \%$ cement replacement by FA whilst GGBS30 and GGBS50 were mixes with $50 \%$ cement replacement by GGBS. The mix proportions of these are shown in Table 2 .

Table 2: Mix proportions and slump of concrete mixes investigated

\begin{tabular}{|c|c|c|c|c|c|c|c|}
\hline $\begin{array}{l}\text { material / } \\
\text { parameter }\end{array}$ & unit & PC30 & GGBS30 & FA30 & PC50 & GGBS50 & FA50 \\
\hline cement $^{*}$ & \multirow{7}{*}{$\mathrm{kg} / \mathrm{m}^{3}$} & 240 & 115 & 193 & 345 & 165 & 270 \\
\hline GGBS & & - & 115 & - & - & 165 & - \\
\hline $\mathrm{FA}$ & & - & - & 82 & - & - & 115 \\
\hline gravel & & 1102 & 1187 & 1319 & 1205 & 1151 & 1250 \\
\hline sand & & 799 & 721 & 560 & 615 & 683 & 533 \\
\hline free water & & 158 & 150 & 144 & 160 & 165 & 135 \\
\hline total water & & 198 & 190 & 181 & 197 & 203 & 171 \\
\hline free w/b & - & 0.66 & 0.65 & 0.52 & 0.46 & 0.50 & 0.35 \\
\hline slump & $\mathrm{mm}$ & 150 & 120 & 120 & 135 & 120 & 100 \\
\hline
\end{tabular}

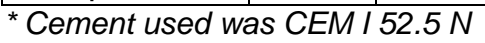

\subsubsection{Mixing, casting, curing and testing procedures}

All concrete mixes were batched using a $0.1 \mathrm{~m}^{3}$ capacity horizontal pan mixer. Binder and aggregate were placed first in the mixing pan and dry-mixed for one minute. Water was then added and mixing continued for a further five minutes. The workability was assessed by carrying out the slump test according to BS EN 12350-2:2000. Concrete cube specimens (100 mm size) were subsequently cast in two layers in single- and three-gang steel moulds, and each layer was compacted using a vibrating table.

Two different curing procedures were used:

- Standard curing for which the concrete specimens, inside single cube moulds, were covered with wet hessian and a polythene sheet immediately after casting and left to 
cure at room temperature conditions (approximately $20^{\circ} \mathrm{C}$ ) for a day. They were subsequently demoulded and placed inside a water bath set at $20^{\circ} \mathrm{C}$.

- Adiabatic curing - The adiabatic temperature rise due to hydration of cement will occur if there are no heat losses from the fresh concrete. To achieve this state it is necessary to either heavily insulate the concrete or alternatively to ensure that the environment in which the concrete is stored is at the same, or nearly the same, temperature as the concrete. The latter approach was adopted in this study. Concrete (150 mm cube) was cast in a steel box lined with $20 \mathrm{~mm}$ expanded polystyrene for insulation and heavy duty polythene to prevent moisture loss. The specimen was then placed into a programmable computer controlled curing tank and two copper/constantan thermocouples were inserted in it through a hole in the top of the box. Two more copper/constantan thermocouples were used to monitor the temperature of the water in the tank. The thermocouples were all connected to a computer which not only recorded the temperatures but also was set to activate the water heating system when the temperature difference between the water and the concrete was $>1{ }^{\circ} \mathrm{C}$. It can be assumed, based on the fact that there was no temperature drop after the maximum had been reached, that there was only very little heat loss and thus no adjustment was needed for the results. A schematic diagram of the setup of the programmable computer control curing tank used for adiabatic tests is shown in Fig. 11. In addition, concrete specimens, inside three-gang moulds, were sealed using a cling film and tape and placed inside the programmable computer controlled curing tank so that the compressive strength could be determined for the adiabatically curing regime. The adiabatically cured concrete specimens remained in the computer controlled tank until the concrete reached its maximum adiabatic temperature, usually one week after casting. Once the adiabatic temperature rise stopped, the remaining concrete specimens were removed from the tank, demoulded, wrapped with wet Hessian and polythene sheet and placed inside curing cabinets set at the final adiabatic temperature. 
The testing ages for the standard cured specimens were 1, 2, 3, 5, 7, 14, 28, 42, 84, 156 and 365 days, while adiabatically cured concrete specimens were tested at 1, 2, 3, 5, 7, 14 and 28 days. At each testing age 3 specimens from each curing regime were tested in order to determine a mean compressive strength.

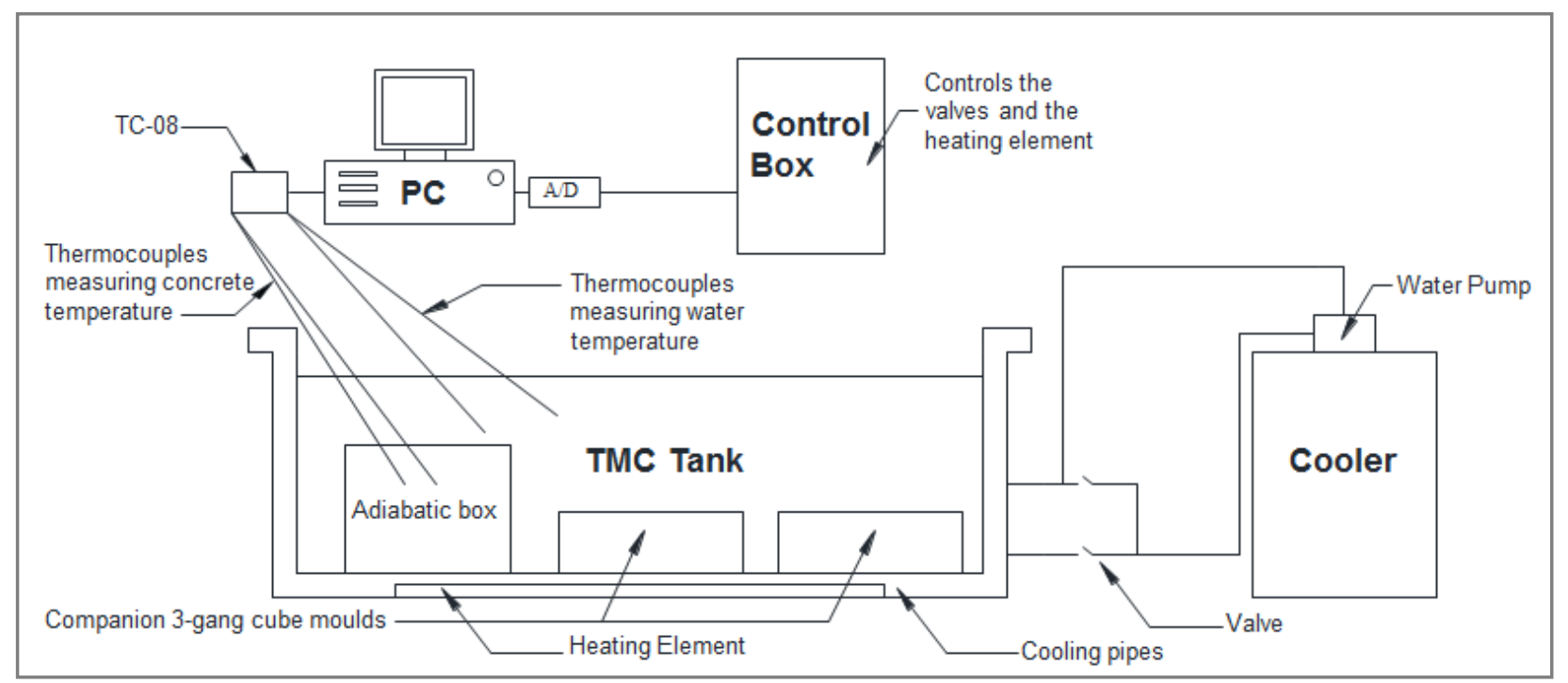

Fig. 11: Setup of the adiabatic test apparatus

\subsection{Results and discussion}

The cube compressive strengths of all the mixes investigated are first presented. The svalues from their strength development with time determined by regression analysis are then compared to the values from Eq. (2). The maturity function is then shown to be based on the Arrhenius function with the "apparent" activation energy being fixed at $33.3 \mathrm{~kJ} / \mathrm{mol}$ irrespective of the binder type used. Adiabatic temperature histories are then presented and subsequently used with the maturity functions for estimating the strength development for non-isothermal curing temperatures.

\subsubsection{Cube compressive strength development}

Table 3 shows the compressive strengths obtained for $20^{\circ} \mathrm{C}$ and adiabatic curing regimes. Not all concretes had the intended 50 and $30 \mathrm{~N} / \mathrm{mm}^{2}$ strength; most notably the GGBS50 that had only $42 \mathrm{~N} / \mathrm{mm}^{2}$ at 28-days. 
Table 3: Compressive strength of the concrete mixes for $20^{\circ} \mathrm{C}$ and adiabatic curing regimes

\begin{tabular}{|c|c|c|c|c|c|c|c|c|c|c|c|c|}
\hline \multirow{2}{*}{ testing age } & \multicolumn{2}{|c|}{ PC30 } & \multicolumn{2}{|c|}{ GGBS30 } & \multicolumn{2}{|c|}{ FA30 } & \multicolumn{2}{|c|}{ PC50 } & \multicolumn{2}{|c|}{ GGBS50 } & \multicolumn{2}{|c|}{ FA50 } \\
\hline & $20^{\circ} \mathrm{C}$ & Ad. & $20^{\circ} \mathrm{C}$ & Ad. & $20^{\circ} \mathrm{C}$ & Ad. & $20^{\circ} \mathrm{C}$ & Ad. & $20^{\circ} \mathrm{C}$ & Ad. & $20^{\circ} \mathrm{C}$ & Ad. \\
\hline$d$ & \multicolumn{2}{|c|}{$\mathrm{N} / \mathrm{mm}^{2}$} & \multicolumn{2}{|c|}{$\mathrm{N} / \mathrm{mm}^{2}$} & \multicolumn{2}{|c|}{$\mathrm{N} / \mathrm{mm}^{2}$} & \multicolumn{2}{|c|}{$\mathrm{N} / \mathrm{mm}^{2}$} & \multicolumn{2}{|c|}{$\mathrm{N} / \mathrm{mm}^{2}$} & \multicolumn{2}{|c|}{$\mathrm{N} / \mathrm{mm}^{2}$} \\
\hline 1 & 7 & 13 & 2 & 3 & 7 & 12 & 21 & 31 & 5 & 12 & 13 & 24 \\
\hline 2 & 13 & 22 & 4 & 9 & 13 & 20 & 30 & 35 & 10 & 28 & 22 & 38 \\
\hline 3 & 18 & 25 & 7 & 14 & 17 & 25 & 35 & 37 & 15 & 37 & 28 & 46 \\
\hline 5 & 20 & 26 & 10 & 21 & 21 & 32 & 41 & 39 & 21 & 43 & 34 & 53 \\
\hline 7 & 23 & 29 & 13 & 25 & 24 & 34 & 43 & 39 & 26 & 42 & 38 & 56 \\
\hline 14 & 28 & 29 & 19 & 29 & 28 & 39 & 47 & 41 & 34 & 45 & 43 & 56 \\
\hline 28 & 31 & 31 & 25 & 31 & 35 & 39 & 50 & 49 & 42 & 47 & 51 & 57 \\
\hline 42 & 32 & - & 28 & - & 37 & - & 53 & - & 43 & - & 58 & - \\
\hline 84 & 33 & - & 31 & - & 46 & - & 55 & - & 51 & - & 59 & - \\
\hline 156 & 33 & - & 34 & - & 47 & - & 59 & - & - & - & 66 & - \\
\hline 365 & 32 & - & 37 & - & 47 & - & 56 & - & - & - & 67 & - \\
\hline
\end{tabular}

Ad.: adiabatic curing

-: not determined

\subsection{2 s-value}

The s-values for all the different concretes have been obtained from Eq. (2) and by regression analysis of the actual strength development data. A commercially available statistical analysis software has been used to obtain the best fit of Eq. (1) by keeping the svalue as variable. The results are shown in Table 3.

At first sight the s-values obtained with the two approaches may appear to be quite different. The values obtained for PC concretes from Eq. (2) (last column) are higher than those from regression analysis (second-last column) whilst those for GGBS are lower. The ones for FA mixes are lower but less than those for GGBS.

The fit of the strength-relationships with s-values from Eq. (2) was therefore expected not to be very good. Nonetheless, the fit appears to be quite good, see Fig. 12 (a) and the improvement from using actual regression s-values is not significant. 
Table 4: Comparison between s-value determined from Eq. (2) and regression analysis for $20{ }^{\circ} \mathrm{C}$ curing $\left(c_{1}\right.$ and $c_{2}$ are 0.481 and 0.441 respectively since the cement used was CEM I $52.5 \mathrm{~N}$ )

\begin{tabular}{|l|c|c|c|c|}
\hline \multirow{2}{*}{ mix ID } & $\begin{array}{c}\mathrm{SCM} \\
\text { replacement }\end{array}$ & $\begin{array}{c}\text { 28-day } \\
\text { compressive } \\
\text { strength }\end{array}$ & $\begin{array}{c}\text { s-value } \\
\text { obtained from } \\
\text { regression }\end{array}$ & $\mathrm{s}=\mathrm{c}_{1} \cdot \mathrm{w} / \mathrm{b}+\mathrm{c}_{2} \cdot \mathrm{scm} / \mathrm{b}$ \\
\cline { 2 - 5 } & $\mathrm{w} .-\%$ & $\mathrm{~N} / \mathrm{mm}^{2}$ & - & - \\
\hline PC30 & 0 & 31 & 0.263 & 0.317 \\
\hline PC50 & 0 & 50 & 0.183 & 0.221 \\
\hline FA30 & 30 & 35 & 0.401 & 0.382 \\
\hline FA50 & 30 & 51 & 0.327 & 0.301 \\
\hline GGBS30 & 50 & 25 & 0.589 & 0.533 \\
\hline GGBS50 & 50 & 42 & 0.489 & 0.461 \\
\hline
\end{tabular}
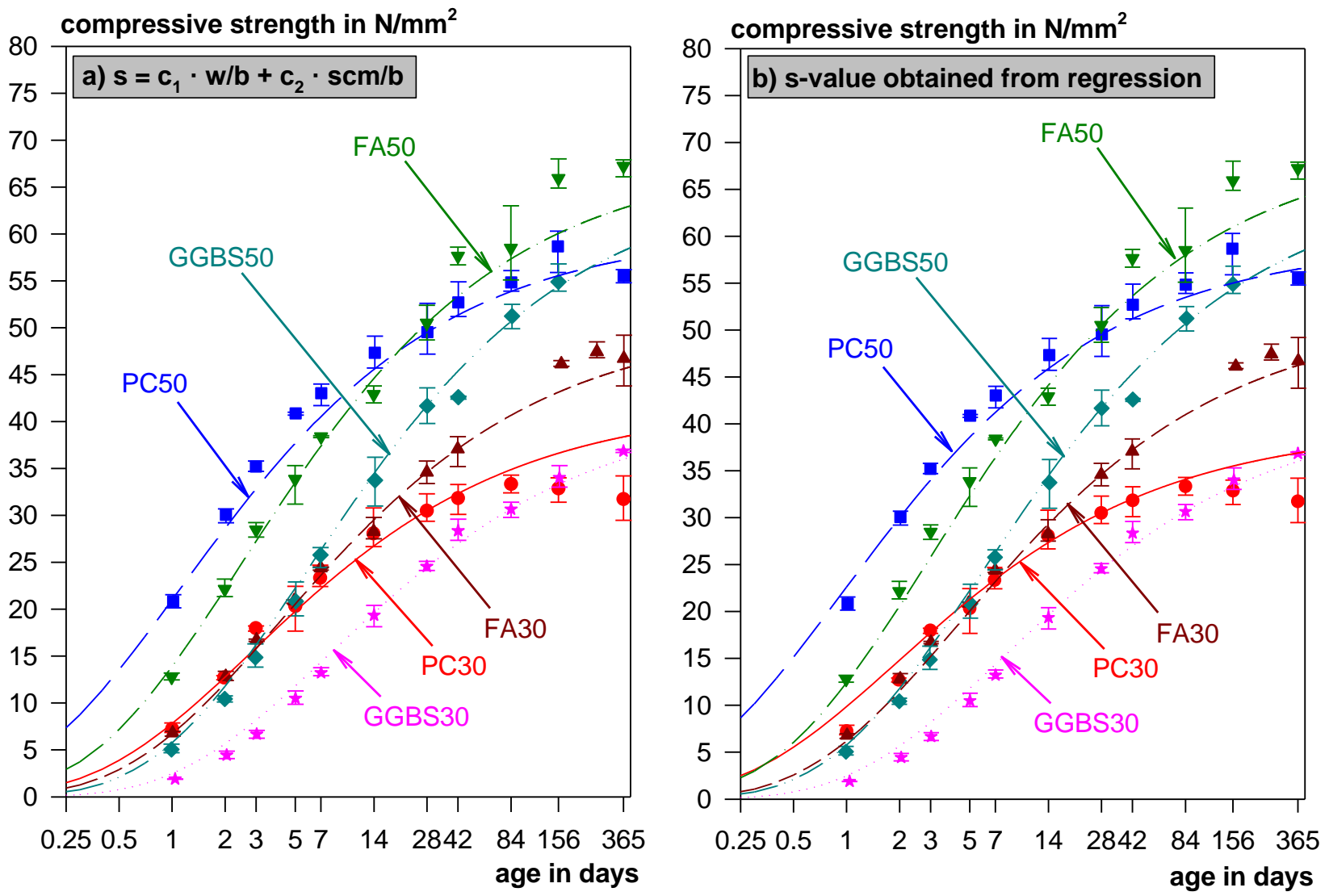

Fig. 12: Regression through experimental data at standard curing temperature $\left(20^{\circ} \mathrm{C}\right)$ using Eq. (1)

For FA50 the discrepancy between prediction and measurement was relatively high, whereas for FA30 the fit is good. To check whether long term strength can be predicted adequately, strength data for a concrete age of one year were taken from the data base (239 
concretes) and analysed analogously to paragraph 2.3. Fig. 13 shows the results separately for the different binder types.

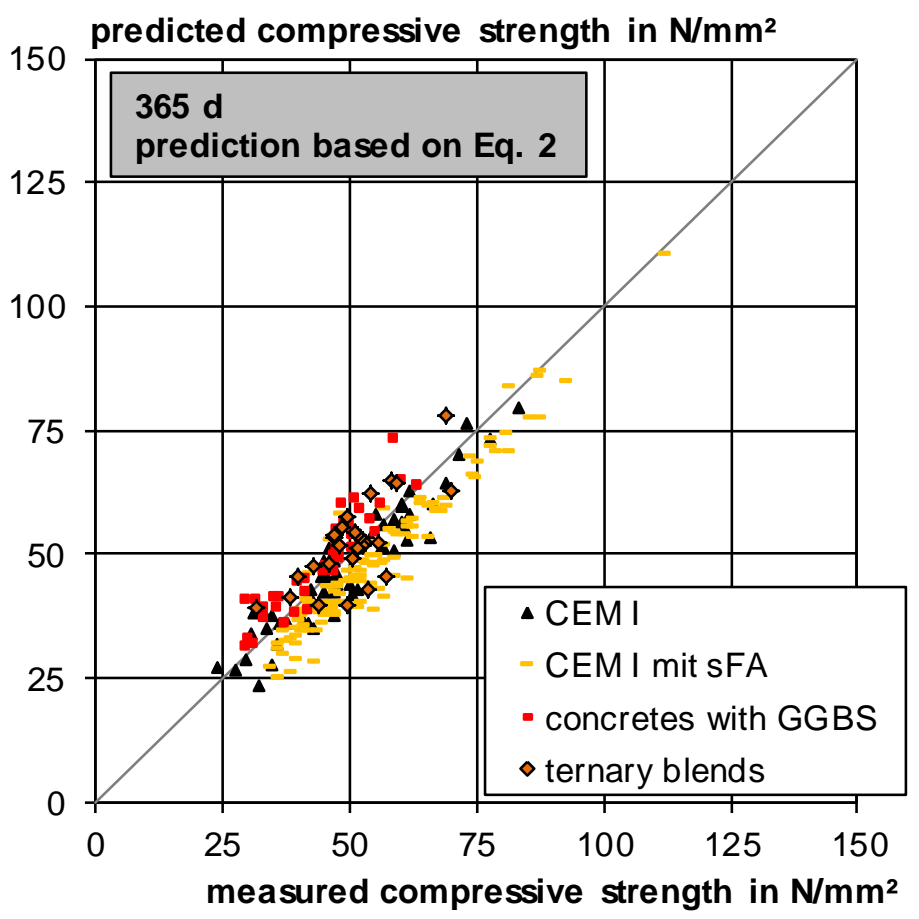

Fig. 13: Correlation between predicted and measured compressive strength at an age of $365 \mathrm{~d}$

There are systematic differences between the different types of binders. The average errors $\left(\Delta f_{c m}=f_{c m, \text { measured }}-f_{c m, \text { predicted }}\right)$ of the available data were calculated:

CEM I concretes:

average $\Delta \mathrm{f}_{\mathrm{Cm}, \mathrm{CEMI}}=2.4 \mathrm{~N} / \mathrm{mm}^{2}$

GGBS concretes:

average $\Delta f_{\mathrm{cm}}, \mathrm{GGBS}=-4.8 \mathrm{~N} / \mathrm{mm}^{2}$

FA concretes:

average $\Delta \mathrm{f}_{\mathrm{cm}, \mathrm{FA}}=5.5 \mathrm{~N} / \mathrm{mm}^{2}$

Concretes with ternary blends: average $\Delta \mathrm{f}_{\mathrm{cm} \text {, ternary }}=-1.6 \mathrm{~N} / \mathrm{mm}^{2}$

It can be concluded that on the long term, there is a difference between the two SCM. For concretes with GGBS the late strength is overestimated with the model based on Eq. 2, whereas for fly ash, the late strength is underestimated. Therefore for ternary blends the fit can be quite good. 


\subsubsection{Maturity function for estimating the strength development for adiabatically cured concretes}

Eq. (1) in combination with the s-value calculated from Eq. (2) might be used to predict early age strength based on 28-day strengths. The latter are normally specified for design purposes, but the former are important to contractors e.g., (1) for accelerated construction schedules that put a new, repaired or overlaid pavement into service and which require adequate concrete strength to withstand traffic loads and (2) in structural elements, for the early removal of forms and props or the application of post-tensioning, and the termination of curing in cold weather. The factors affecting strength at early ages must be considered. These include, amongst others, (a) the composition of the concrete mixture, such as cement type and percentage of SCM in the binder and (b) the curing temperature of the concrete. The latter depends not only on the binder type used, but also on the size and shape of the structural element, the ambient temperature and whether thermal insulation is used or not. The concrete temperature inside a structural element is unlikely to be $20{ }^{\circ} \mathrm{C}$. The adiabatic curing regime is an extreme situation, since it is assumed that no heat is lost, but nonetheless it is useful in quantifying the accuracy in the estimations of maturity functions.

Maturity functions aim to account for the combined effect of time and temperature on strength devleopment. They account for the "sensitivity" of different binders to temperature in different ways but these can be compared with "equivalent age" which represents "the duration of curing period at the reference temperature that would result in the same maturity as the curing period at other temperature". For example, the maturity function proposed by Hansen and Pedersen [79], that assumes the rate of strength development obeys the Arrhenius law (referred to as Arrhenius in this paper):

$t_{e}=\sum e^{-\frac{E_{a}}{R} \cdot\left(\frac{1}{T_{a}}-\frac{1}{T_{s}}\right)} \cdot \Delta t$

\section{Where}

$t_{e}$ is the equivalent age in days, 
$T_{\alpha}$ is the average temperature of concrete during time interval $\Delta t$ in $K$,

$\mathrm{T}_{\mathrm{s}}$ is the specified reference temperature in $\mathrm{K}$,

$E_{a}$ is the apparent activation energy in $\mathrm{J} / \mathrm{mol}$ and

$\mathrm{R}$ is the universal gas constant in $\mathrm{J} / \mathrm{K} \cdot \mathrm{mol}$.

In this case the age conversion factor is:

$\alpha=e^{-\frac{E_{a}}{R} \cdot\left(\frac{1}{T_{a}}-\frac{1}{T_{s}}\right)}$.

The fib model code's maturity function is based on the Arrhenius function with $E_{a}=$ $33,256 \mathrm{~J} / \mathrm{mol}, \mathrm{R}=8.314 \mathrm{~J} /(\mathrm{K} \cdot \mathrm{mol})$ and specified reference temperature $\mathrm{T}_{\mathrm{s}}=20^{\circ} \mathrm{C}$ :

$t_{T}=\sum_{i=1}^{n} \Delta t_{i} e^{\left[13.65-\frac{4000}{273+T_{a}\left(\Delta t_{i}\right)}\right]}$

Where

$\mathrm{t}_{\mathrm{T}}$ is the temperature-adjusted concrete age with replaces $t$ in Equation 1 in days.

$\left(\Delta \mathrm{t}_{\mathrm{i}}\right)$ is the number of days where a temperature $\mathrm{T}_{\alpha}$ prevails in days,

$\mathrm{T}_{\alpha}\left(\Delta \mathrm{t}_{\mathrm{i}}\right)$ is the average temperature of concrete during time interval $\Delta \mathrm{t}_{\mathrm{i}}$ in ${ }^{\circ} \mathrm{C}$,

The main difference to Eq. (4) is therefore the "apparent" activation energy that is fixed at $33.3 \mathrm{~kJ} / \mathrm{mol}$ whilst the Arrhenius function allows different values for this. Apparent activation energies are normally determined for isothermally cured strength development data of "equivalent" mortars. The procedure, which is described in ASTM C1074-11, requires the "equivalent" mortars to have the same $\mathrm{w} / \mathrm{b}$ ratio as the concretes and the sand to binder ratios need to be equal to the coarse aggregate to binder ratios of the concrete. Values from the "equivalent" mortars for concretes described here have been reported in Soutsos et. al (2016) [80]. These are shown in Fig. 14 and it can be seen that the fib model code's selection of $33.3 \mathrm{~kJ} / \mathrm{mol}$ as apparent activation energy is between those of PC50 and PC30. 
The FA ones are slightly below those of the equivalent PC concretes whilst those for GGBS are considerably higher. The effect these have on the strength estimates will be examined next.

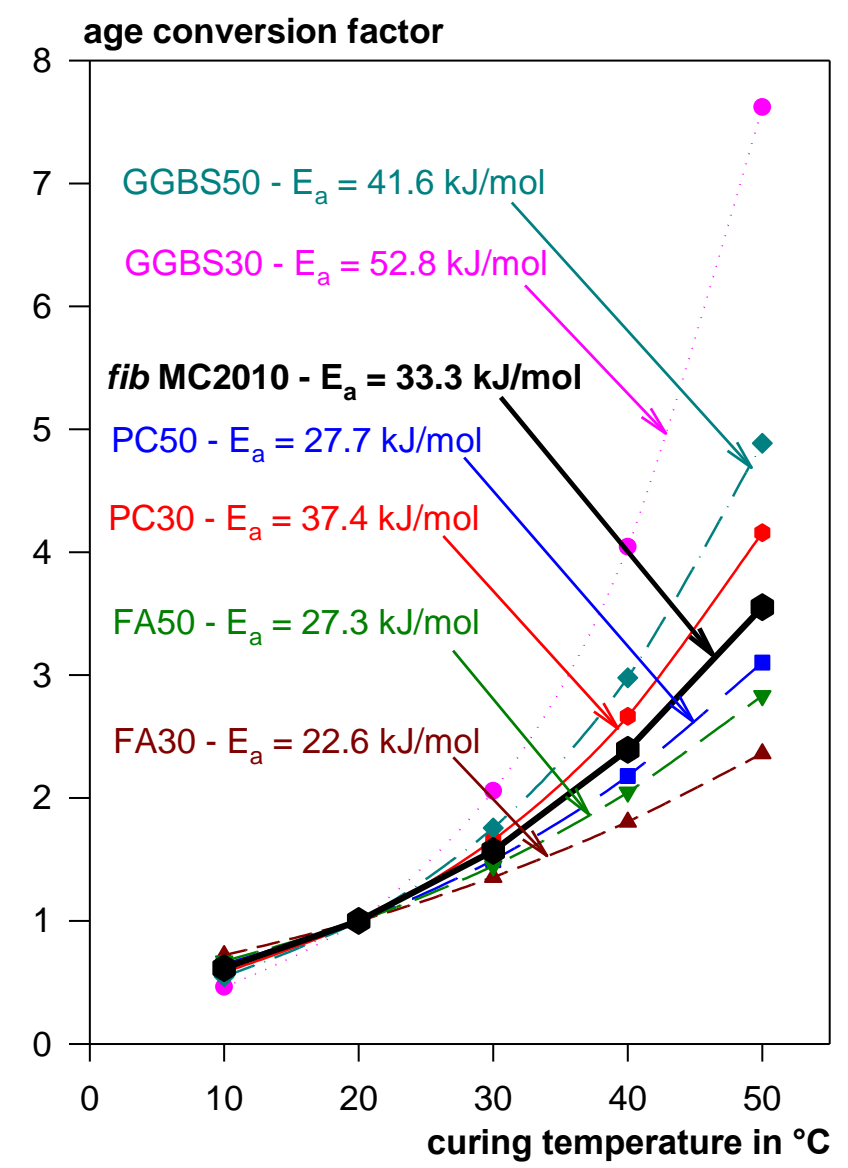

Fig. 14: Effect of temperature and binder composition on the age conversion factor

\subsubsection{Adiabatic temperature history}

The adiabatic temperature history of all the concretes is shown in Fig. 15. The Portland cement concretes of 50 and $30 \mathrm{~N} / \mathrm{mm}^{2}$ strengths had a temperature rise of $48{ }^{\circ} \mathrm{C}$ and $32.5^{\circ} \mathrm{C}$ respectively from a casting temperature of approximately $20{ }^{\circ} \mathrm{C}$. GGBS at $50 \%$ of total binder is effective in reducing the adiabatic temperature rise considerably, i.e. down to $38^{\circ} \mathrm{C}$ and $24{ }^{\circ} \mathrm{C}$ for grades 50 and $30 \mathrm{~N} / \mathrm{mm}^{2}$ respectively. $\mathrm{FA}$ at $30 \%$ of total binder reduces the peak temperature rise of $50 \mathrm{~N} / \mathrm{mm}^{2}$ concrete down to $39{ }^{\circ} \mathrm{C}$ but there was no reduction for the $30 \mathrm{~N} / \mathrm{mm}^{2}$ concrete. This appears to be abnormal except that similar trends have been 
obtained from in-situ temperature rises during the DTI Core project [9]. A possible explanation for this could be that the contribution to heat by FA has been affected by the low water to binder ratio of 0.35 for the $50 \mathrm{~N} / \mathrm{mm}^{2}$ concrete. This suggestion is made because FA has been shown to have lower strength contribution at lower water to binder ratios [81]. The higher strength mixes reach higher temperatures, as expected. It must also be noted that the binder contents of FA50 and FA30 are higher, at 385 and $275 \mathrm{~kg} / \mathrm{m}^{3}$, from the equivalent PC concretes which had 330 and $240 \mathrm{~kg} / \mathrm{m}^{3}$ of cement. The heat output of the binder, which was experimentally determined through isothermal calorimeter as described in [81], has been estimated to be $314 \mathrm{~kJ} / \mathrm{kg}$ and $331 \mathrm{~kJ} / \mathrm{kg}$ for PC50 and PC30, $240 \mathrm{~kJ} / \mathrm{kg}$ and $256 \mathrm{~kJ} / \mathrm{kg}$ for FA50 and FA30 and $220 \mathrm{~kJ} / \mathrm{kg}$ and $257 \mathrm{~kJ} / \mathrm{kg}$ for GGBS50 and GGBS30 respectively. As can be seen, the heat output per $\mathrm{kg}$ of binder is slightly reduced at lower water to binder ratios which confirms previous findings [82, 90, 91, 92, 93].

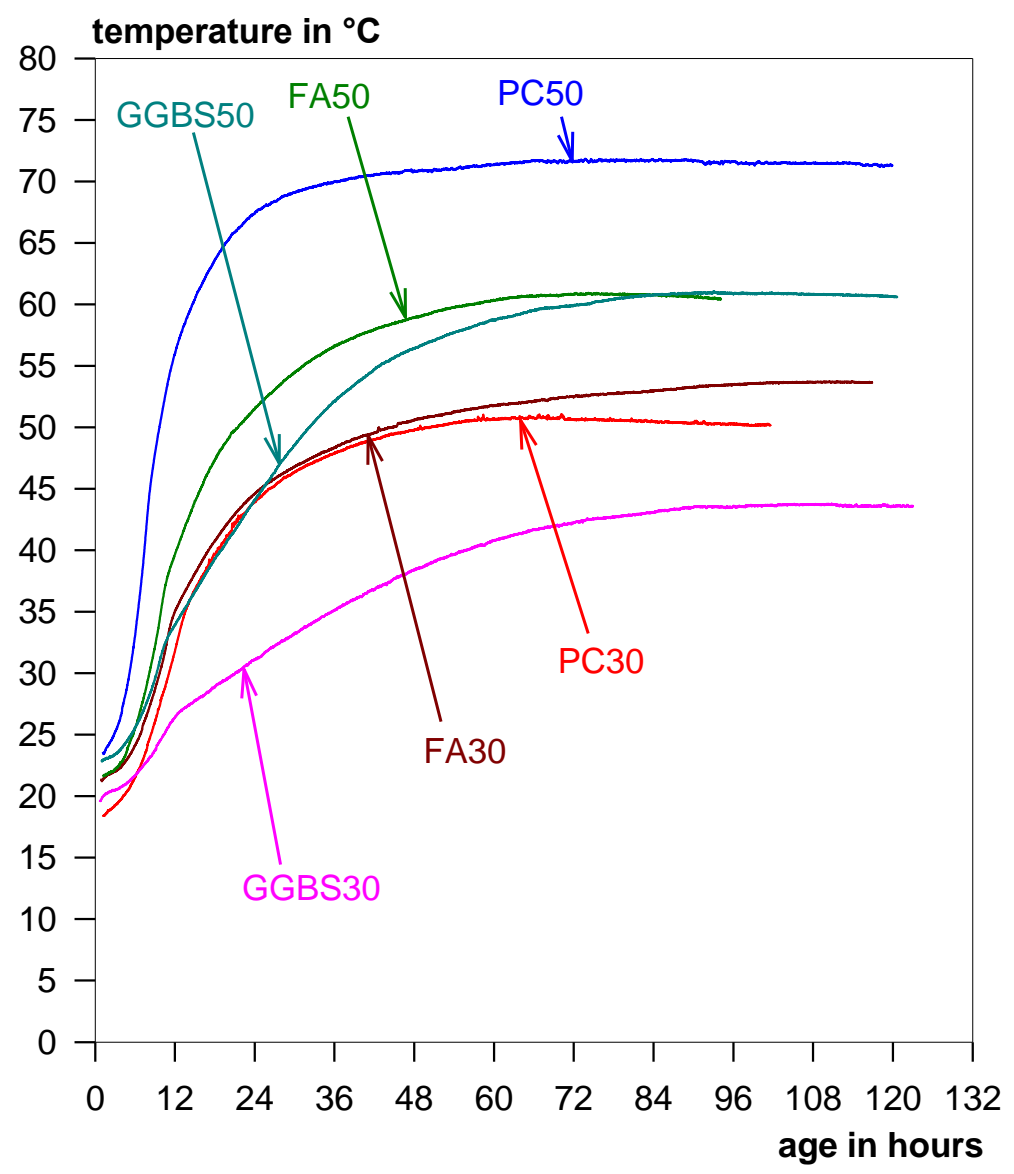

Fig. 15: Adiabatic temperature of investigated concretes 


\subsubsection{Concrete strength estimates}

The Arrhenius function required the apparent activation energies of all six concretes which were previously determined $[80,82]$ according to ASTM C1074-11 method and they were PC30 $=37.4 \mathrm{~kJ} / \mathrm{mol}$, GGBS30 $=52.8 \mathrm{~kJ} / \mathrm{mol}$, FA30 $=22.6 \mathrm{~kJ} / \mathrm{mol}$, PC50 $=27.7 \mathrm{~kJ} / \mathrm{mol}$, GGBS50 $=41.6 \mathrm{~kJ} / \mathrm{mol}$ and FA50 $=27.3 \mathrm{~kJ} / \mathrm{mol}$ as shown in Fig. 14. These were found to be in good agreement with values in literature [83 - 87]. The equivalent age $t_{e}$ at time $t$ was calculated using Eq. (4). The specified reference temperature, $T_{s}$, used was $293^{\circ} \mathrm{K}\left(20^{\circ} \mathrm{C}\right)$. The fib model code's procedure requires that the temperature-adjusted concrete age $t_{T}$, which is the equivalent age, is calculated from Eq. (6) with $T_{a}$ being the average temperature (in ${ }^{\circ} \mathrm{C}$ ) of concrete during time interval $\Delta t$, which is the temperature history the concrete is subjected to (in this case, these were the temperature histories recorded during the adiabatic tests). The value of $t_{T}$ obtained was then substituted for $t$ at Equation 1 with the s-value as previously determined from Eq. (2). The value of equivalent age obtained, $t_{e}$, was then substituted for $t$ in Eq. (1) with s-value as previously determined for the strength data obtained for the concrete cured at $20^{\circ} \mathrm{C}$.

The adiabatic temperature histories, Fig. 15, were thus converted into estimated strength development curves and these are shown in Fig. 16 and Fig. 17. The "Arrhenius" labelled indicates that (a) the s-value was obtained by regression of the strength data obtained for the concrete cured at $20^{\circ} \mathrm{C}$ and (b) the "apparent" activation energy was determined according to ASTM C1074-11. The "Modified fib" labelled one indicates that (a) the s-value was obtained from Eq. (2) and (b) the "apparent" activation energy was $33.3 \mathrm{~kJ} / \mathrm{mol}$ irrespective of the binder. The calculated strength values estimated using the "Modified fib" are considerably good especially at early ages, for all tested mixtures except the PC50, thus increasing confidence in the use of Eq. (2) for estimating the s-value without determining this by regression of actual strength development data. It is most noticeable for the PC50 that the maturity functions overestimate long term strength. This is due to the inability of maturity 
functions to account for the detrimental effect that high early age temperatures have on later age strength.

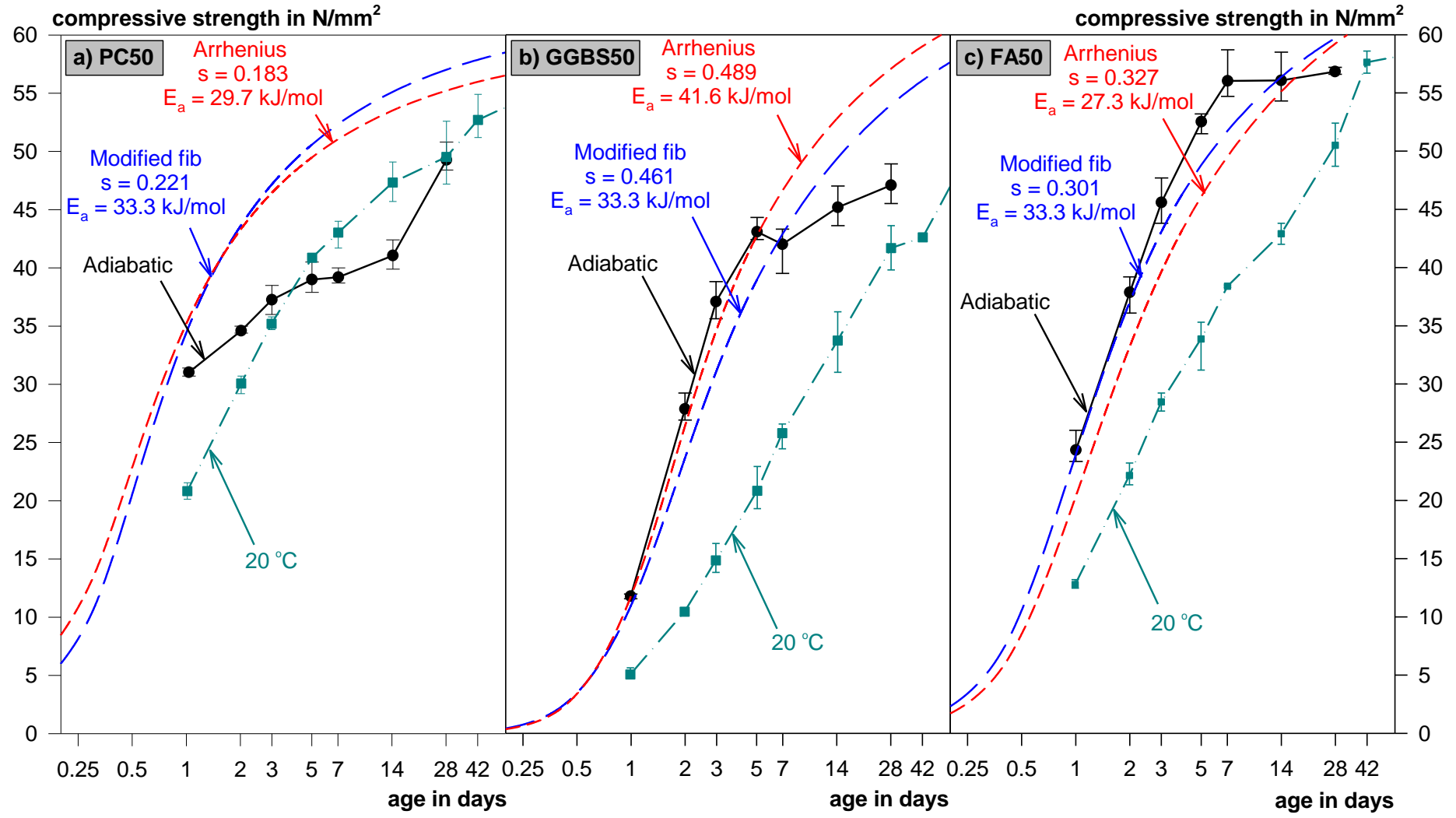

Fig. 16: Adiabatic strength estimates for $50 \mathrm{~N} / \mathrm{mm}^{2}$ strength concretes 


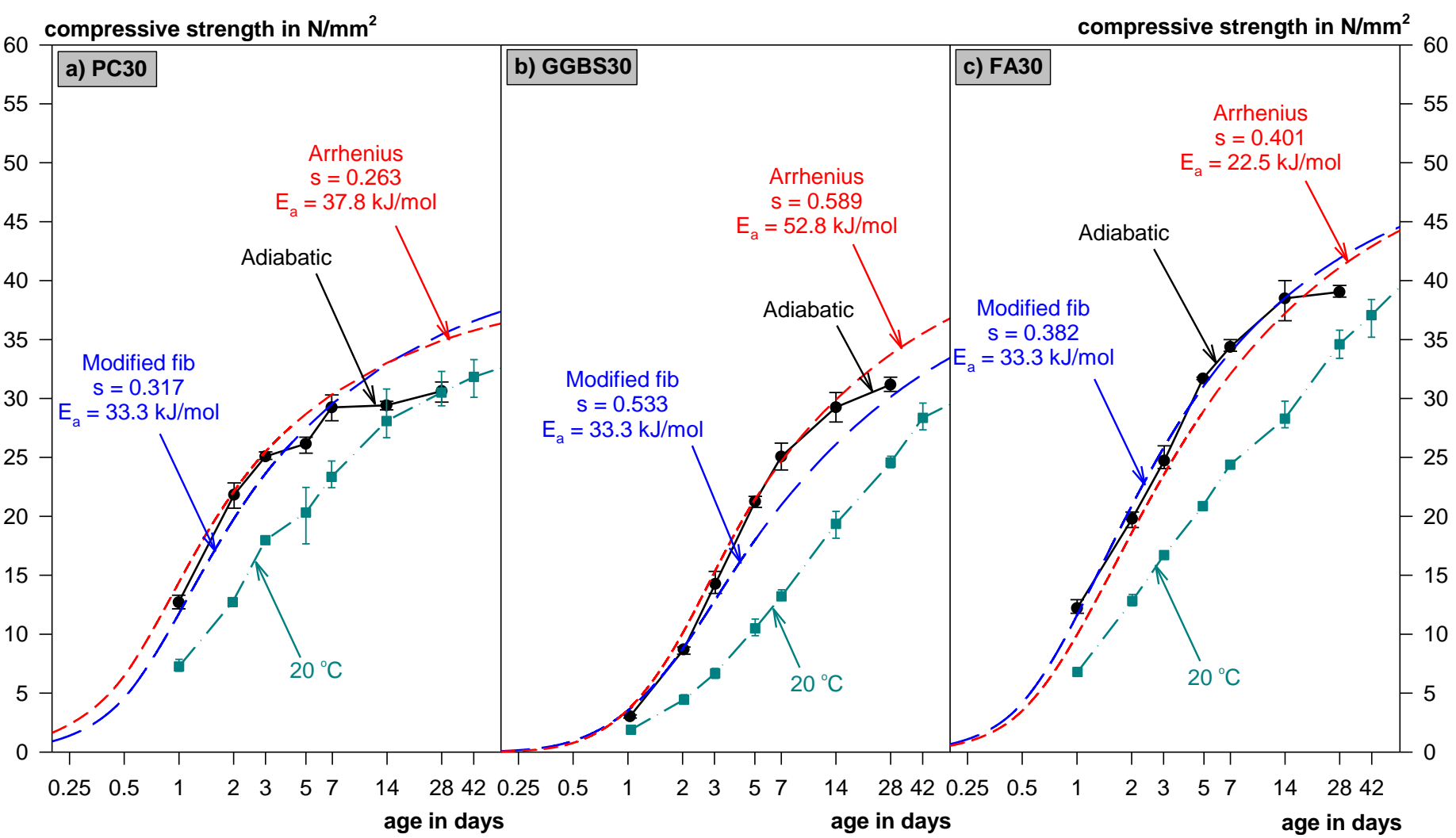

Fig. 17: Adiabatic strength estimates for $30 \mathrm{~N} / \mathrm{mm}^{2}$ strength concretes

The temperature of the PC50 rises above $60{ }^{\circ} \mathrm{C}$, within 12 hours after casting. This is approximately the highest temperature recorded for FA50 and GGBS50 but these occur much later at 48 and 72 hours respectively. The temperature rise under nearly adiabatic curing regime relies on the heat evolution from the binder. The increase in temperature for FA50 and GGBS50 is delayed by several hours and significant rises only occur even more hours later as a result of the induction period [88]. As the hydration reaction is required to have progressed significantly before high temperatures occur, the detrimental effect to long term strengths is significantly reduced. It is for this reason that it is recommended that curing cycles, e.g. for precast concrete products, should have a "delay period" before the "temperature rise period" [89].

The early age temperature rise of the PC50 appears to have had significant detrimental effect to the ultimate strength and strength estimates do not improve after 1 day but become worse. This detrimental effect of high early age curing temperature on later age strength has become known as the "cross-over" effect (firstly reported by Mclntosh in 1956 [94]) and is 
believed be due to the formation of dense hydrated phases around the unreacted cement particles, preventing further hydration [95, 96]. Furthermore, this deviation of strength estimates from the actual measured values is less pronounced for especially the FA and GGBS concretes because of (a) the longer "delay period" and (b) the "cross-over" effect occurring much later than Portland cement, i.e. beyond 28-days as can be seen from Fig. 16 and Fig. 17.

The above discussed trends can be also seen in Fig. 18 and Fig. 19 where the estimated to actual strength ratio is plotted versus age. These figures also show that the Arrhenius labelled estimates do not considerably improve with the use of specific coefficients of the particular concrete, i.e. the s-values determined from regression analysis and the use of "apparent" activation energies. The improvements are mainly for the GGBS concretes which have considerably higher "apparent" activation energies, i.e. 41.6 and $52.8 \mathrm{~kJ} / \mathrm{mol}$ for GGBS50 and GGBS30 respectively, from the $33.3 \mathrm{~kJ} / \mathrm{mol}$ used in the fib model code. The small differences in "apparent" activation energies, as well as the "delay period" for PC and FA concretes, may have made the improvements in strength estimates appear to be small. This may be different if the concretes were cured isothermally at an elevated temperature especially if these high temperatures were applied immediately after casting. 


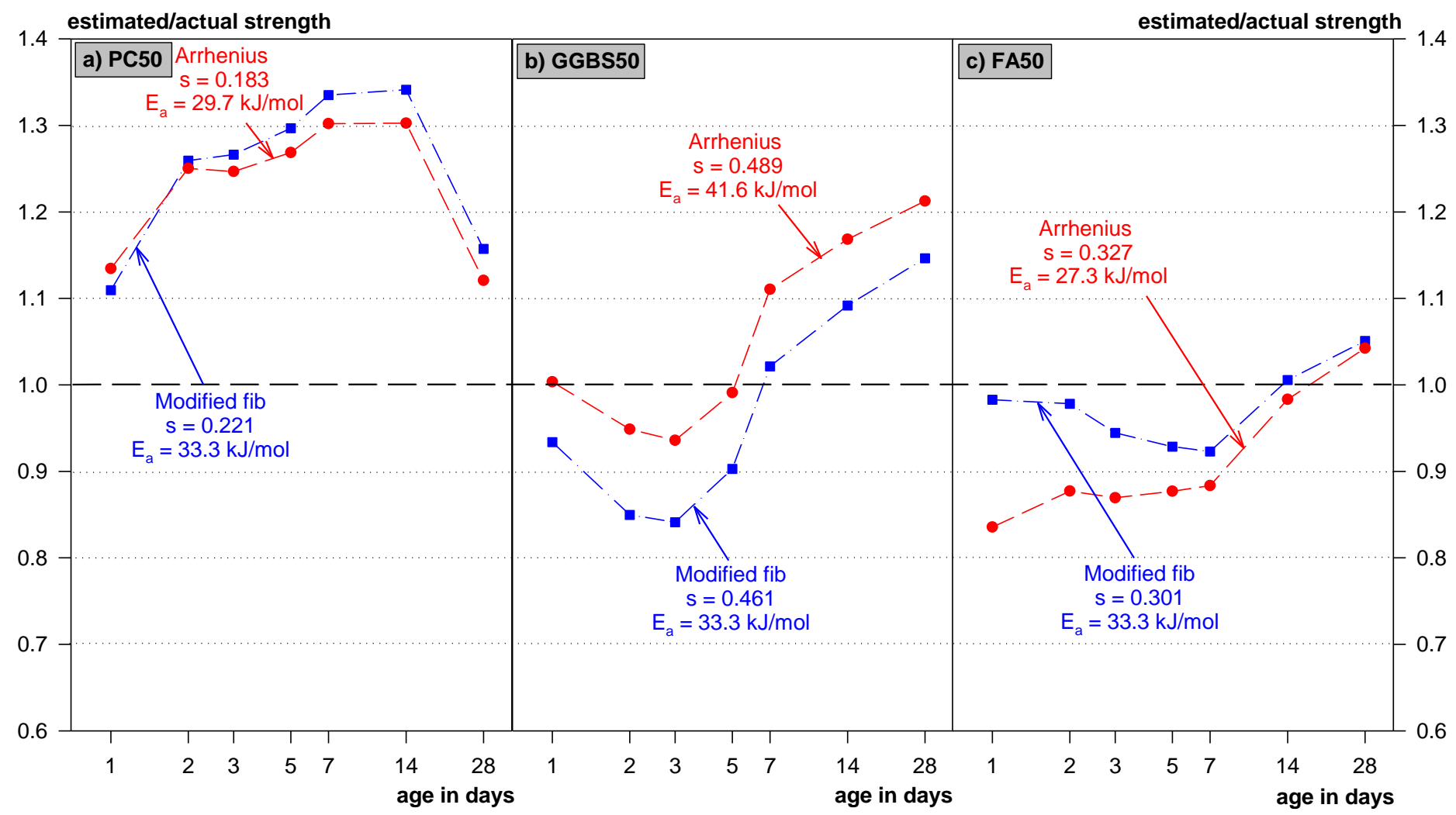

Fig. 18: Estimated vs. actual strength ratios for $50 \mathrm{MPa}$ strength concretes

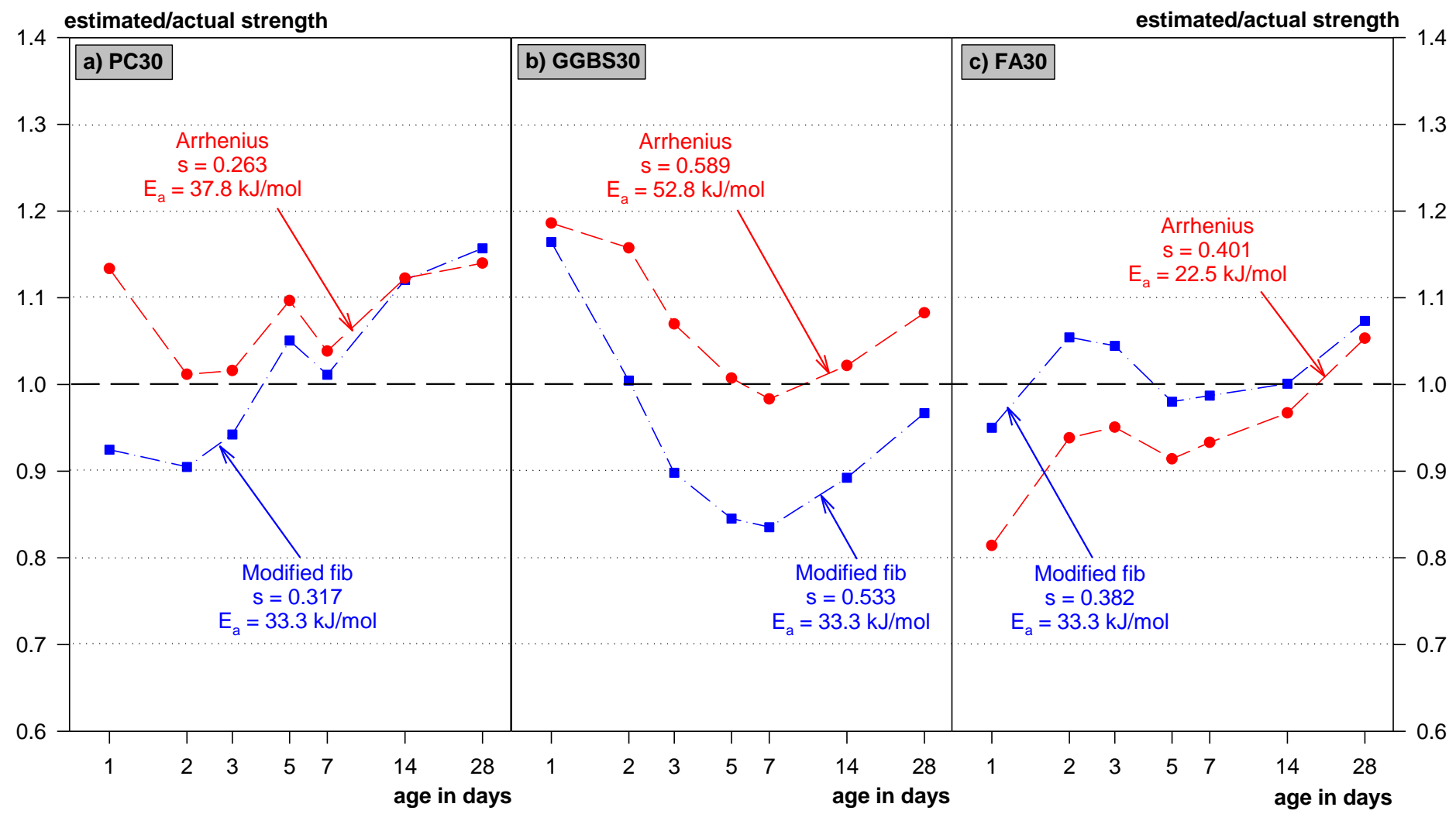

Fig. 19: Estimated vs. actual strength ratios for $30 \mathrm{MPa}$ strength concretes 


\section{Summary and outlook}

This paper provides an approach to predict the compressive strength development of concrete with GGBS and silicious fly ash including ternary blends. The calculation is based on an e-function that is defined in the fib Model code. The Model code considers the strength class of the cement with a so-called s-value. In this paper the effect of GGBS and fly ash on the s-value was quantified based on a large concrete database. The fly ash content of the selected concretes ranges from 10 to 63 wt.-\% related to the binder. Most of the concrete mixes are in a range of 20 to 35 wt.- $\%$ fly ash, The GGBS concretes range from 7.5 to 85 wt.- $\%$ GGBS in the binder, most of them having 25 to 60 wt.-\% GGBS,

The s-value of a specific concrete can be calculated based on the SCM content and water/binder ratio. This relationship between s-values and w/b plus $\mathrm{SCM} / \mathrm{b}$ ratios has been tested on laboratory cast specimens with 50 and $30 \%$ cement replacement with GGBS and FA respectively. These showed that:

- The s-values from this relationship, when compared to those obtained from regression analysis, did differ but the estimated strength development with time was quite good up to an age of $91 \mathrm{~d}$ and the improvement from using actual regression svalues was not significant.

- Late strength predictions will lead to an overestimation of the strength of concretes with GGBS and an underestimation of the strength of concretes with FA. The absolute error is in the order of $5 \mathrm{~N} / \mathrm{mm}^{2}$ after one year for both types of binders.

- The fib model code's maturity function is based on the Arrhenius function with a fixed apparent activation energy of $E_{a}=33.3 \mathrm{~kJ} / \mathrm{mol}$. This apparent activation energy is between those of PC50 and PC30.

- The $\mathrm{E}_{\mathrm{a}}$ of the FA concretes are slightly below those of the equivalent PC concretes whilst those for GGBS concretes are considerably higher.

- Use of these different "apparent" activation energies that are specific to the concrete mix constituents do not considerably improve the strength estimates. 
- The small differences in "apparent" activation energies, as well as the small "delay period" for PC and FA concretes, may have made the improvements in strength estimates from the use of "apparent" activation energies specific to the particular concrete appear to be small.

- The use of "apparent" activation energies specific to the particular concrete may result in more accurate estimates for concretes cured isothermally at an elevated temperature especially if these high temperatures were applied immediately after casting.

\section{References}

1. Saul AGA (1951) Principles underlying the steam curing of concrete at atmospheric pressure. Magazine of Concrete Research 2(6), pp 127-140

2. Lew H, Fattel S, Shaver J, Reinhold T, Hunt B (1979) Investigation of construction failure of reinforced concrete cooling tower at Willow Island. West Virginia, Report no. PB-80192883, National Engineering Lab (NBS), Washington

3. Feld J, Carper K (1997) Construction Failure. John Wiley and Sons, New York

4. Barnett SJ, Soutsos MN, Bungey JH, Millard SG (2007) Fast-Track Construction with Slag Cement Concrete: Adiabatic Strength Development and Strength Prediction. ACI Materials Journal 104(4), pp 388-396

5. Brooks AG, Schindler AK, Barnes RW (2007) Maturity method evaluated for various cementitious materials. J. Mater. Civ. Eng. 19(12), pp 1017-1025

6. Galobardes I, Cavalaro S, Goodier Cl, Austin S, Rueda A (2015) Maturity method to predict the evolution of the properties of sprayed concrete. Construction and Building Materials 79, pp 357-369

7. Sofi M, Mendis PA, Baweja D (2012) Estimating early-age in situ strength development of concrete slabs. Construction and Building Materials 29, pp 659-666

8. Yikici TA, Chen $\mathrm{H}(2015)$ Use of maturity method to estimate compressive strength of mass concrete. Construction and Building Materials 95, pp 802-812

9. Soutsos M, Hatzitheodorou A, Kwasny J, Kanavaris F (2016) Effect of in-situ temperature on the early-age strength development of concrete with supplementary cementitious materials. Construction and Building Materials 103, pp 105-116

10. fib Model Code for Concrete Structures 2010. Ernst \& Sohn publishing company. ISBN: 978-3-433-03061-5

11. Ambroise J, Pera J (1995) Development of Self-Levelling High Volume Fly Ash Concrete. Milwaukee: Fifth CANMET/ACI International Conference on Fly Ash, Silica Fume, Slag and Natural Pozzolans in Concrete, Supplementary Papers, pp 361-372

12. Atis CD (2005) Strength Properties of High-Volume Fly Ash Roller Compacted and Workable Concrete, and Infuence of Curing Condition. Cement and Concrete Research 35(6), pp 1112-1121 
13. Baert G (2009) Physico-Chemical Interactions in Portland-Cement - (High-Volume) Fly Ash Binders. Gent, Universiteit Gent, Faculteit Ingenieurswettenschappen, Proefschrift

14. Bilgeri $P$ (2009) Sanierung der südlichen Start- und Landebahn am Flughafen Köln/ Bonn mit Portlandhüttenzement. Erstmalige Anwendung des CEM II/A-S 42,5 N (st) auf einer Flugbetriebsfläche. Beton-Informationen 49(1/2), pp 3-14

15. Bilodeau A, Malhotra VM (1992) Concrete Incorporating High Volumes of ASTM Class F Fly Ashes: Mechanical Properties and Resistance to Deicing Salt Scaling and to Chloride-Ion Penetration. Istanbul: Fourth CANMET/ACI International Conference on Fly Ash, Silica Fume, Slag and Natural Pozzolans in Concrete, Proceedings 1 (Malhotra VM (Ed.)), pp 319-349

16. Bouzoubaa N, Fournier B (2003) Optimization of Fly Ash Content in Concrete Part I: Non-Air-Entrained Concrete Made without Superplasticizer. Cement and Concrete Research 33(7), pp 1029-1037

17. Brameshuber W, Rasch S, Uebachs S, Rankers R (2008) Untersuchungen und Abschätzung der Leistungungsfähigkeit von Hüttensanden in Bindemittel für Beton. Aachen: Institute of Building Materials Research (ibac), RWTH Aachen University, Research report no. F 7037

18. Brameshuber W, Spörel F (2004) Verbundverhalten von Selbstverdichtenden Betonen des Kombinats- und Stabilisierungstyps. Aachen: Institute of Building Materials Research (ibac), Research report no. F 906

19. Brameshuber W, Uebachs S (2008) Entwicklung von Selbstverdichtenden Betonen des Stabilisierer-Typs zum speziellen Einsatz im Wohnungsbau. Aachen: Institute of Building Materials Research (ibac), RWTH Aachen University, Research report no. F 869

20. Brameshuber W, Pierkes R (2004) Anrechnung von Flugasche in Beton bei Frostbelastung gemäß der Expositionsklasse XF2. Aachen: Institute of Building Materials Research (ibac), RWTH Aachen University, Research report no. F 871

21. Brameshuber W, SchießI P, Uebachs S, Brandes C, Eck T (2005) Einfluss von Flugasche auf den Frost-Tausalz-Widerstand von Beton. Aachen: Institute of Building Materials Research (ibac), RWTH Aachen University, Research report no. F 759

22. Brameshuber W, Schröder P (2002) Auswirkung der gemeinsamen Anrechnung von Silicastaub und Flugasche auf Festbetoneigenschaften. Aachen: Institute of Building Materials Research (ibac), RWTH Aachen University, Research report no. F 758

23. Brameshuber W, Spörel F (2004) Untersuchungen zum Ermüdungsverhalten von Rüttelbeton und selbstverdichtendem Beton unter zyklischer Druckschwellbeanspruchung. Aachen: Institute of Building Materials Research (ibac), RWTH Aachen University, Research report no. F 881

24. Brameshuber W, Steinhoff J (2010) Gemeinsame Verwendung von Flugasche und Hüttensand als Zusatzstoff im Beton. Aachen: Institute of Building Materials Research (ibac), RWTH Aachen University, Research report no. F 960/2

25. Brameshuber W, Vollpracht A (2009) Flugaschebetone gleicher Leistungsfähigkeit. Aachen: Institute of Building Materials Research (ibac), RWTH Aachen University, Research report no. F 920

26. Brameshuber W, Vollpracht A; Rasch S (2009) Erarbeitung von Anwendungsregeln für Hüttensand als Betonzusatzstoff gemäß der harmonisierten Europäischen Stoffnorm. Aachen: Institute of Building Materials Research (ibac), RWTH Aachen University, Research report no. F 7038, Fraunhofer IRB Verlag ISBN 978-3-8167-8147-9

27. Brooks JJ, Wainwright PJ, Boukendakji M (1992) Influence of Slag Type and Replacement Level on Strength, Elasticity, Shrinkage, and Creep of Concrete. Istanbul: Fourth 
CANMET/ACI International Conference on Fly Ash, Silica Fume, Slag, and Natural Pozzolans in Concrete, Proceedings 2 (Malhotra VM (Ed.)), pp 1325-1341

28. Cabrera JG, Hopkins CJ, Woolley GR, Lee RE et al (1986) Evaluation of the Properties of British Pulverized Fuel Ashes and their Influence on the Strength of Concrete. Madrid: Second CANMET/ACI International Conference on Fly Ash, Silica Fume, Slag and Natural Pozzolans in Concrete, Proceedings 1 (Malhotra VM (Ed.)), pp 115-144

29. Carette GG, Bilodeau A, Chevrier RL, Malhotra VM (1993) Mechanical Properties of Concrete Incorporating High Volumes of Fly Ash from Sources in the U.S. ACI Materials Journal 90(6), pp 535-544

30. Carette GG, Malhotra VM (1983) Early-Age Strength Development of Concrete Incorporating Fly Ash and Condensed Silica Fume. Detroit: First CANMET/ACI International Conference on the Use of Fly Ash, Silica Fume, Slag and Other Mineral By-Products in Concrete, Proceedings 2, pp 765-784

31. Carette GG, Malhotra VM (1986) Characterization of Canadian Fly Ashes and their Relative Performance in Concrete. Madrid: Second CANMET/ACI International Conference on Fly Ash, Silica Fume, Slag and Natural Pozzolans in Concrete (Malhotra VM (Ed.)), pp 6.1-52

32. Coppola L, Troli R, Zaffaroni P, Belz G, Collepardi M (1998) Influence of Unburned Carbon in the Performance of Concrete Mixtures. Bangkok: Sixth CANMET/ACI International Conference on Fly Ash, Silica Fume, Slag and Natural Pozzolans in Concrete, Proceedings 1 (Malhotra VM (Ed.)), pp 257-271

33. Dhir RK, Hubbard FH, Munday JGL, Jones MR, Duerden SL (1988) Contribution of PFA to Concrete Workability and Strength Development. Cement and Concrete Research 18(2), pp 277-289

34. Domone PL, Soutsos MN, Nyame BK (1995) Properties of high-strength concrete mixes containing PFA and ggbs. Magazine of Concrete Research 47(173), pp 355-367

35. Erntroy HC (1992) The Effect on Compressive Strength of the Glass Content of Blastfurnace Slag When Used as A Cementitous Constituent. Zement-Kalk-Gips 45(10), pp 533-535

36. Galeoata D, Giammatteo MM, Marino R (1995) Structural Concrete Incorporating High Volume of Fly Ash. Milwakee: Fifth CANMET/ACI International Conference on the Use of Fly Ash, Silica Fume, Slag and Natural Pozzolans in Concrete, Proceedings 1 (Malhotra VM (Ed.)), pp 25-42

37. Gardner NJ (1990) Effect of Temperature on the Early-Age Properties of Type I, Type III, and Type I/Fly Ash Concretes. Journal of the ACI 87(1), pp 68-78

38. Gardner NJ, Sau PL (1986) Strength Development and Durability of CSA Type 30 Cement/Slag Concretes. Madrid: Second CANMET/ACI International Conference on Fly Ash, Silica Fume, Slag and Natural Pozzolans in Concrete, Supplementary Papers (Malhotra VM (Ed.)), pp 16.1-24

39. Giaccio G, Violini D, Zappitelli J, Zerbino R (1989) Compressive Strength and Elastic Properties of Fly Ash Concrete Elaborated with Different Cement Types. Trondheim: Third CANMET/ACI International Conference on Fly Ash, Silica Fume, Slag and Natural Pozzolans in Concrete, Supplementary Papers, (Malhotra VM (Ed.)), pp 188-202

40. Goma F (1992) Concrete Incorporating a High Volume of ASTM Class C Fly Ash With High Sulfate Content. Istanbul: Fourth CANMET/ACI International Conference on Fly Ash, Silica Fume, Slag, and Natural Pozzolans in Concrete, Proceedings 1 (Malhotra VM (Ed.)), pp 403-417 
41. Gruyaert E (2011) Effect of Blast Furnace Slag as Cement Replacement on Hydration, Microstructure, Strength and Durability of Concrete. Gent, Universiteit Gent, Faculteit Ingenieurswetenschappen en Architectuur, Proefschrift

42. Haque MN, Kayali O (1998) Properties of High-Strength Concrete Using a Fine Fly Ash. Cement and Concrete Research 28(10), pp 1445-1452

43. Hornain H, Miersman F, Marchand J (1992) Influence of Residual Carbon in Fly Ash on Microstructure and Strength Development of Mortars and Concretes. Istanbul: Fourth CANMET/ACI International Conference on Fly Ash, Silica Fume, Slag, and Natural Pozzolans in Concrete, Proceedings 1 (Malhotra VM (Ed.)), pp 21-36

44. Kim JK, Park YD, Sung KY, Lee SG (1992) The Production of High Strength Fly Ash Concrete in Korea. Istanbul: Fourth CANMET/ACI International Conference on Fly Ash, Silica Fume, Slag, and Natural Pozzolans in Concrete. Supplementary Papers, pp 109119

45. Lewandowski R (1983) Einfluß unterschiedlicher Flugaschequalitäten und -zugabemengen auf die Betoneigenschaften. Betonwerk- und Fertigteil-Technik 49(1), pp 11-15 49(2), pp 105-110 49(3), pp 152-158

46. Longe A; Torrent RJ(1986) Methods of Addition of Blast Furnace Slag: Their Effect on the Compressive Strength of Mortars and Concretes. Madrid: Second CANMET/ACI International Conference on Fly Ash, Silica Fume, Slag and Natural Pozzolans in Concrete, Proceedings 2 (Malhotra VM (Ed.)), pp 1381-1400

47. Malhotra VM (1983) Strength and Durability Characteristics of Concrete Incor-pora-ting a Pelletized Blast Furnace Slag. Detroit: First CANMET/ACI International Conference on the Use of Fly Ash, Silica Fume, Slag and Other Mineral By-Products in Concrete, Proceedings 2, pp 891-921

48. Meusel JW, Rose JH (1983) Production of Granulated Blast Furnace Slag at Sparrows Point, and the Workability and Strength Potential of Concrete Incorparating the Slag. Detroit: First CANMET/ACI International Conference on the Use of Fly Ash, Silica Fume, Slag and Other Mineral By-Products in Concrete, Proceedings 2, pp 867-890

49. Müller C, Eickschen E, Breitenbücher R, Reimann C (2014) Überprüfung des Zeitbeiwerts für Fahrbahndeckenbetone. Beton-Informationen 54(1), pp 3-16

50. Naik, TR, Singh S, Ramme B (1998) Mechanical Properties and Durability of Concrete Made With Blended Fly Ash. ACI Materials Journal 95(4), pp 454-462

51. Naik TR, Singh SS, Ramme B (1997) Effect of Source and Amount of Fly Ash on Mechanical and Durability Properties of Concrete. Sidney: Fourth CANMET/ACI International Conference on Durability of Concrete, Proceedings I, (Malhotra VM (Ed.)), pp 157-188

52. Nakamura N, Sakai M, Swamy RN (1991) Effect of slag fineness on the engineering properties of high strength concrete. Sheffield, UK: International Conference on Blended Cements in Construction, Proceedings (Swamy RN (Ed.)), pp 302-316

53. Nakamura N, Sakai M, Koibuchi K, lijima Y (1986) Properties of High-Strength Concrete Incorporating Very Finely Ground Granulated Blast Furnace Slag. Madrid: Second CANMET/ACI International Conference on Fly Ash, Silica Fume, Slag and Natural Pozzolans in Concrete, Proceedings 2 (Malhotra VM (Ed.)), pp1361-1380

54. Nobis C, Vollpracht A, Brameshuber W (2015) Entwicklung von Anwendungsregeln für Hüttensandmehl als Betonzusatzstoff. Aachen: Institute of Building Materials Research (ibac), RWTH Aachen University, Research report no. F 997

55. Ramezanianpour AA, Malhotra VM (1995) The Effect of Curing on the Compressive Strength, Resistance to Chloride-ion Penetration and Porosity of Concretes Incorporating Slag or Fly Ash or Silica Fume. Cement \& Concrete Composites 17(2), pp 125-133 
56. Ramyar K (1992) The Effect of Fly Ash Inclusion on the Compressive Strength of Fly Ash Mortars and Concretes. Istanbul: Fourth CANMET/ACI International Conference on Fly Ash, Silica Fume, Slag, and Natural Pozzolans in Concrete. Supplementary Papers, Istanbul, May, pp 139-157

57. Rickert J, Vollpracht A (2014) Analysenkonzept zur Bestimmung von Spurenelementen in Eluaten zementgebundener Baustoffe. Düsseldorf: Forschungsinstitut der Zementindustrie, Aachen: Institute of Building Materials Research (ibac), final report to the IGF project $16989 \mathrm{~N}$

58. Savva A, Manita P, Sideris KK (2005) Influence of Elevated Temperatures on the Mechanical Properties of Blended Cement Concretes Prepared with Limestone and Siliceous Aggregates. Cement and Concrete Composites 27(2), pp 239-248

59. SchießI P, Härdtl R (1992) Untersuchungen an Mörteln und Betonen mit Steinkohlenflugasche für eine erweiterte Anrechenbarkeit der Steinkohlenflugasche (VGB-Projekt 87), Part I and II and Appendix. Aachen: Institute of Building Materials Research (ibac), RWTH Aachen University, Research reports no. F 236 and F 323

60. SchießI P, Wiens U, Breit, W. (1994) Reduzierung des Alkalitätsdepots durch Puzzolane. Aachen: Institute of Building Materials Research (ibac), RWTH Aachen University, Research report no. F 397

61. Scholz E, Wierig HJ (1988) Untersuchungen über den Einfluß von Flugaschezusätzen auf das Carbonatisierungsverhalten von Beton. I. Ergänzung 1988. Hannover: Institut für Baustoffkunde und Materialprüfung, (Research report)

62. Sivasundaram V, Carette GG, Malhotra VM (1989) Properties of Concrete Incorporating Low Quantity of Cement and High Volumes of Low-Calcium Fly Ash. Trondheim: Third CANMET/ACI International Conference on Fly Ash, Silica Fume, Slag and Natural Pozzolans in Concrete, Proceedings 1 (Malhotra VM (Ed.)), pp 45-71

63. Thomas MDA, Matthews JD, Haynes CA (1989) The Effect of Curing on the Strength and Permeability of PFA Concrete. Trondheim: Third CANMET/ACI International Conference on Fly Ash, Silica Fume, Slag and Natural Pozzolans in Concrete, Proceedings 1 (Malhotra VM (Ed.)), pp 191-217

64. Veba Kraftwerke Ruhr AG (1987) Druckfestigkeit von Beton mit Flugasche: Eine Vergleichsuntersuchung. Gelsenkirchen-Bühr: VEBA Kraftwerke Ruhr AG

65. Vollpracht $A$ (2015) Data collection regarding compressive strength of concretes from material testing at ibac between 1978 and 2015. Aachen: Institute of Building Materials Research (ibac), RWTH Aachen University, unpublished

66. Zimbelmann RK, Junggunst $\mathrm{J}(1999)$ Hochleistungsbeton mit hohem Flugaschegehalt. Beton- und Stahlbetonbau 94(2), pp 58-65

67. Kern E (1993) Technologie des hochfesten Betons: Anwendungsbericht mit praktischen Beispielen. Beton 43,(3), pp 109-115

68. Schrage I, Springenschmid R (1996) Versuche über das Kriechen und Schwinden hochfesten Betons. Teile 1+2. Beton- und Stahlbetonbau 91(2), pp 30-36, and 91(3), pp 6871

69. Fiala H, Teufer M, Blobner A (2005) Hochfester Beton B 85 ohne Zusatz von Silikatstaub. Beton 55(4), pp 154-155,158

70. Blobner A, Israel D, Möller W, Winzer R (2004) Silicafreier hochfester Beton mit Dyckerhoff Veridur: Ein neuer Portlandhüttenzement EN 197-1 - CEM II/ A-S 52,5 R. Beton-Informationen 44,(1), pp 3-7

71. Theile V, Hildebrandt H, Brüggemann HG (1996) Hochhausensemble mit projektbezogenen Sonderbetonen: Moderne Verfahrenstechnik für Massenbeton und hochfesten Beton. Beton 46(9), pp 535-540 
72. Nicolay J, Stark J (1993) Dauerhaftigkeit von Weißbeton B 85: Prüfungen an hochfesten Betonen. Beton 3,(9), pp 444-448

73. Paulus S (1991) Hochfeste Betone mit ausreichender Verarbeitbarkeit. Aachen, Fachhochschule, Fachbereich Bauingenieurwesen, diploma thesis

74. Ludwig HM (2012) Zukünftige Zemente und ihre Eigenschaften. Beton 62(5), pp 158162,164-165

75. Schultz W, van Diest J (2011) Ertüchtigung von Brückenbauwerken unter fließendem Verkehr. Ostfildern: 2. Kolloquium Erhaltung von Bauwerken, Technische Akademie Esslingen, (Raupach M (Ed.)), pp 153-156

76. Bergner H (1997) Rißbreitenbeschränkung zwangbeanspruchter Bauteile aus hochfestem Normalbeton. Berlin: Schriftenreihe des Deutschen Ausschusses für Stahlbeton (Beuth), no. 482

77. Held M (1992) Ein Beitrag zur Herstellung und Bemessung von Druckgliedern aus hochfestem Normalbeton (B60-B125). Darmstadt, Technische Hochschule, Fachbereich Konstruktiver Ingenieurbau, Dissertation

78. Dahlhoff U (1994) Untersuchungen an Mörteln und Beton zur Entwicklung von Hochofenzement mit erhöhter Anfangsfestigkeit. Aachen, Technische Hochschule, Fachbereich 3, Dissertation

79. Hansen PF, Pedersen EJ (1997) Maturity computer for controlled curing and hardening of concrete, Nord. Betong, 1, pp 21-25

80. Soutsos M, Hatzitheodorou A, Kanavaris F, Kwasny J (2016) Effect of temperature on the strength development of mortar mixes with ground granulated blast-furnace slag and fly ash. Magazine of Concrete Research [Submitted for publication].

81. Soutsos MN (1992) Mix design, workability, adiabatic temperature and strength development of high strength concrete. PhD thesis, University College London.

82. Hatzitheodorou A (2007) In-situ strength development of concretes with supplementary cementitious materials, PhD thesis, University of Liverpool

83. Soutsos MN, Turu'allo G, Owens K, Kwasny J, Barnett SJ, Basheer PAM (2013) Maturity Testing of Lightweight Self-Compacting and Vibrated Concretes, Construction and Building Materials 47, pp 118-125

84. Barnett SJ, Soutsos MN, Millard SG, Bungey JH (2006) Strength development of mortars containing ground granulated blast-furnace slag: Effect of curing temperature and determination of apparent activation energies, Cement and Concrete Research, Volume 36, Issue 3, pp 434-440

85. Poole JL, Riding KA, Juenger MCG, Folliard KJ, Schindler AK (2010) Effects of supplementary cementitious materials on apparent activation energy, Journal of ASTM International 7(9), $16 \mathrm{pp}$

86. Barnett SJ, Soutsos MN, Millard SG, Bungey JH (2007) Temperature Rise and Strength Development in Laboratory-Cast Structural Elements Containing Slag, Warsaw: Ninth CANMET/ACI International Conference on Fly Ash, Silica Fume, Slag and Natural Pozzolans in Concrete, (Malhotra VM (Ed.)), ISBN 978-0-87031-241-0, pp 37-50

87. Poole JL, Riding KA, Folliard KJ, Juenger MCG, Schindler AK (2007) Methods for calculating apparent activation energy for Portland cement, ACI Materials Journal 104(1), pp 303-311

88. Shi C, Krivenko P, Roy D (2006) Alkali-Activated Cements and Concretes. Taylor \& Francis, pp 65

89. Neville AA, Brooks JJ (2010) Concrete Technology. Pearson Education, $2^{\text {nd }}$ Edition, $p$ 188 
90. Pane I, Hansen W (2005) Investigation of blended cement hydration by isothermal calorimetry and thermal analysis. Cement and Concrete Research 35, pp 1155-1164.

91. Zhang Y, Sun W, Liu S (2002) Study on the hydration heat of binder paste in highperformance concrete. Cement and Concrete Research 32, pp 1483-1488.

92. Riding KA, Poole JL, Folliard KJ, Juenger MCG, Schindler AK (2012) Modeling hydration of cementitious systems. ACI Materials Journal 109(2), pp 225-234

93. Turu'allo G (2013) Early age strength development of GGBS concrete cured under different temperatures. PhD thesis, University of Liverpool, UK.

94. McIntosh, JD (1956) The effects of low-temperature curing on the compressive strength of concrete. Copenhagen: Proceedings of Rilem Symposium on Winter Concreting, Session BII

95. Escalante-Garcia, JI, Sharp, JH (2001) The microstructure and mechanical properties of blended cements hydrated at various temperatures. Cement and Concrete Research 31(5), pp 695-702

96. Escalante, JI, Gomez, LY, Johal, KK, Mendoza, G, Mancha, H, Mendez, J (2011) Reactivity of blast-furnace slag in Portland cement blends hydrated under different conditions. Cement and Concrete Research 31(10), pp 1403-1409 


\section{Annex}

Table A 1: Summary of the collected data on strength development of Portland cement concretes

\begin{tabular}{|l|l|c|cc|c|}
\hline \multicolumn{1}{|c|}{ binder } & $\begin{array}{l}\text { storage } \\
\text { conditions }\end{array}$ & $\begin{array}{c}\text { number of } \\
\text { cements }\end{array}$ & range of w/c-ratio & $\begin{array}{c}\text { number of } \\
\text { concrete mixes }\end{array}$ \\
\hline \multirow{2}{*}{ CEM I, unspecified } & W or FR & 23 & $0.27-0.80$ & 56 \\
& C7 & 1 & 0.32 & 1 \\
\hline \multirow{2}{*}{ CEM I 32.5 R } & W or FR & 1 & $0.47-0.67$ & 3 \\
& C7 & 42 & $0.45-0.75$ & 71 \\
\hline CEM I 42.5 N & W or FR & 4 & $0.23-0.60$ & 9 \\
\hline \multirow{2}{*}{ CEM I 42.5 R } & W or FR & 5 & $0.42-0.68$ & 6 \\
& C7 & 22 & $0.25-0.70$ & 46 \\
\hline \multirow{2}{*}{ CEM I 52.5 N } & W or FR & 2 & 0.50 & 2 \\
& C7 & 2 & $0.35-0.60$ & 4 \\
\hline \multirow{2}{*}{ CEM I 52.5 R } & W or FR & 1 & \multicolumn{2}{|c|}{0.55} & 1 \\
& C7 & 4 & $0.30-0.50$ & 6 \\
\hline
\end{tabular}

* No strength class given (ASTM or Australian standard). Based on the compressive strength of mortar five Portland cements were assigned to strength class $42.5 \mathrm{R}$ or higher [27, 37 $39,43,46]$. Eighteen cements were assigned to strength class $32.5 \mathrm{R}$ or $42.5 \mathrm{~N}[15,16,30$, $31,37,39,44,46-48,50,52,53,55,56,62]$

W: Storage under water until testing at $20 \pm 3{ }^{\circ} \mathrm{C}$

FR: Storage in a fog room with $\geq 95 \% \mathrm{r}$. h. at $20 \pm 3{ }^{\circ} \mathrm{C}$

C7: Storage under water until an age of $7 \mathrm{~d}$ for curing, afterwards air storage, $20 \pm 3^{\circ} \mathrm{C}$ and $60 \%$ or $65 \%$ r. h.

Table A 2: Summary of the collected data on strength development of concretes with sFA

\begin{tabular}{|c|c|c|c|c|c|c|}
\hline binder & $\begin{array}{l}\text { storage } \\
\text { conditions }\end{array}$ & $\begin{array}{l}\text { number } \\
\text { of } \\
\text { cements }\end{array}$ & $\begin{array}{l}\text { number } \\
\text { of sFA }\end{array}$ & $\begin{array}{l}\text { number of } \\
\text { binder } \\
\text { combinations }\end{array}$ & $\begin{array}{l}\text { range of } \\
\text { w/b-ratio }\end{array}$ & $\begin{array}{l}\text { number of } \\
\text { concrete } \\
\text { mixes }\end{array}$ \\
\hline $\begin{array}{l}\text { CEM I, unspecified }{ }^{*} \text {, with } \\
\text { sFA }\end{array}$ & $\begin{array}{l}\text { W or FR } \\
\text { C7 }\end{array}$ & $\begin{array}{c}12 \\
1\end{array}$ & $\begin{array}{c}29 \\
2\end{array}$ & $\begin{array}{c}50 \\
2\end{array}$ & $\begin{array}{c}0.27-0.80 \\
0.31\end{array}$ & $\begin{array}{c}86 \\
2\end{array}$ \\
\hline CEM I 32.5 R with sFA & $\begin{array}{l}\text { W or FR } \\
\text { C7 }\end{array}$ & $\begin{array}{c}1 \\
17\end{array}$ & $\begin{array}{c}1 \\
31\end{array}$ & $\begin{array}{c}3 \\
54\end{array}$ & $\begin{array}{l}0.39-0.56 \\
0.29-0.67\end{array}$ & $\begin{array}{l}12 \\
78\end{array}$ \\
\hline CEM I $42.5 \mathrm{~N}$ with sFA & W or FR & 1 & 1 & 3 & $0.26-0.36$ & 6 \\
\hline CEM I $42.5 \mathrm{R}$ with sFA & $\begin{array}{l}\text { W or FR } \\
\text { C7 }\end{array}$ & $\begin{array}{c}2 \\
11\end{array}$ & $\begin{array}{c}5 \\
13 \\
\end{array}$ & $\begin{array}{c}7 \\
18 \\
\end{array}$ & $\begin{array}{ll}0.42 & -0.48 \\
0.31-0.75\end{array}$ & $\begin{array}{c}7 \\
24\end{array}$ \\
\hline CEM I $52.5 \mathrm{~N}$ with sFA & $\begin{array}{l}\text { W or FR } \\
\text { C7 }\end{array}$ & $\begin{array}{l}2 \\
1 \\
\end{array}$ & $\begin{array}{l}4 \\
1 \\
\end{array}$ & $\begin{array}{l}7 \\
1 \\
\end{array}$ & $\begin{array}{l}0.40-0.50 \\
0.40-0.60\end{array}$ & $\begin{array}{l}7 \\
3 \\
\end{array}$ \\
\hline CEM II/B-V 32.5 R & $\mathrm{C} 7$ & 18 & - & 18 & $0.60-0.75$ & 21 \\
\hline CEM II/B-V 42.5 R & C7 & 1 & - & 1 & 0.60 & 1 \\
\hline
\end{tabular}

* No strength class given (ASTM or Australian standard). Based on the compressive strength of mortar eleven of these cements could be assigned to strength class $32.5 \mathrm{R}$ or $42.5 \mathrm{~N}[15,16,29$ 31,39 (cement C), 44, 55, 62]. One cement was assigned to strength class $42.5 \mathrm{R}$ [39 (cement B)].

w/b: $\quad$ water / binder ratio $(b=$ cement content + SCM content $)$ 
Table A 3: Summary of the collected data on strength development of concretes with GGBS

\begin{tabular}{|c|c|c|c|c|c|c|}
\hline binder & $\begin{array}{l}\text { storage } \\
\text { conditions }\end{array}$ & $\begin{array}{c}\text { number } \\
\text { of } \\
\text { cements }\end{array}$ & $\begin{array}{c}\text { number } \\
\text { of } \\
\text { GGBS }\end{array}$ & $\begin{array}{l}\text { number of } \\
\text { binder } \\
\text { combinations }\end{array}$ & $\begin{array}{l}\text { range of } \\
\text { w/b-ratio }\end{array}$ & $\begin{array}{c}\text { number of } \\
\text { concrete } \\
\text { mixes }\end{array}$ \\
\hline $\begin{array}{l}\text { CEM I, unspecified*, with } \\
\text { GGBS }\end{array}$ & W or FR & 6 & 8 & 21 & $0.29-0.76$ & 64 \\
\hline CEM I 32.5 R with GGBS & C7 & 2 & 12 & 19 & $0.45-0.62$ & 54 \\
\hline CEM I $42.5 \mathrm{~N}$ with GGBS & W or FR & 1 & 1 & 3 & $0.26-0.38$ & 8 \\
\hline CEM I 42.5 R with GGBS & C7 & 5 & 10 & 28 & $0.33-0.60$ & 86 \\
\hline CEM I $52.5 \mathrm{~N}$ with GGBS & W or FR & 2 & 2 & 8 & 0.50 & 8 \\
\hline CEM I 52.5 R with GGBS & $\mathrm{C} 7$ & 1 & 1 & 1 & $0.26-0.42$ & 3 \\
\hline CEM II/A-S $42.5 \mathrm{~N}$ & $\mathrm{C} 7$ & 1 & - & 1 & 0.58 & 1 \\
\hline CEM II/A-S 42.5 R & W or FR & 1 & - & 1 & 0.43 & 1 \\
\hline CEM II/B-S, unspecified* & W or FR & 3 & - & 3 & 0.50 & 3 \\
\hline CEM II/B-S 32.5 R & $\begin{array}{c}\text { W or FR } \\
\text { C7 }\end{array}$ & $\begin{array}{l}1 \\
4 \\
\end{array}$ & - & $\begin{array}{l}1 \\
4 \\
\end{array}$ & $\begin{array}{c}0.43 \\
0.45-0.70\end{array}$ & $\begin{array}{c}1 \\
12 \\
\end{array}$ \\
\hline CEM II/B-S $42.5 \mathrm{~N}$ & $\begin{array}{c}\text { W or FR } \\
\text { C7 }\end{array}$ & $\begin{array}{l}1 \\
1 \\
\end{array}$ & - & $\begin{array}{l}1 \\
1 \\
\end{array}$ & $\begin{array}{c}0.43 \\
0.47-0.67\end{array}$ & $\begin{array}{l}1 \\
3 \\
\end{array}$ \\
\hline CEM II/B-S 42.5 R & $\mathrm{C} 7$ & 1 & - & 1 & $0.50-0.60$ & 3 \\
\hline $\begin{array}{l}\text { CEM II/B-S } 32.5 \mathrm{R} \text { with } \\
\text { GGBS }\end{array}$ & C7 & 3 & 12 & 18 & $0.45-0.60$ & 53 \\
\hline $\begin{array}{l}\text { CEM II/B-S } 42.5 \mathrm{R} \text { with } \\
\text { GGBS }\end{array}$ & C7 & 1 & 6 & 12 & $0.43-0.59$ & 36 \\
\hline CEM III/A, unspecified* & W or FR & 3 & - & 3 & 0.50 & 3 \\
\hline CEM III/A $32.5 \mathrm{~N}$ & $\begin{array}{c}\text { W or FR } \\
\text { C7 }\end{array}$ & $\begin{array}{c}2 \\
13\end{array}$ & $\begin{array}{l}- \\
-\end{array}$ & $\begin{array}{c}2 \\
13 \\
\end{array}$ & $\begin{array}{ll}0.50-0,70 \\
0.30-0.75\end{array}$ & $\begin{array}{c}6 \\
25\end{array}$ \\
\hline CEM III/A 32.5 R & $\begin{array}{c}\text { W or FR } \\
\text { C7 }\end{array}$ & $\begin{array}{l}1 \\
1 \\
\end{array}$ & $\begin{array}{l}- \\
-\end{array}$ & $\begin{array}{l}1 \\
1 \\
\end{array}$ & $\begin{array}{l}0.50-0.69 \\
0.60-0.67\end{array}$ & $\begin{array}{l}3 \\
2 \\
\end{array}$ \\
\hline CEM III/A $42.5 \mathrm{~N}$ & $\begin{array}{c}\text { W or FR } \\
\text { C7 }\end{array}$ & $\begin{array}{l}2 \\
4 \\
\end{array}$ & - & $\begin{array}{l}2 \\
4 \\
\end{array}$ & $\begin{array}{ll}0.43 & -0.52 \\
0.50 & -0.60 \\
\end{array}$ & $\begin{array}{c}3 \\
11 \\
\end{array}$ \\
\hline CEM III/A 42.5 R & $\mathrm{C} 7$ & 3 & - & 3 & 0.5 & 3 \\
\hline CEM III/A $52.5 \mathrm{~N}$ & $\mathrm{C} 7$ & 3 & - & 3 & 0.5 & 3 \\
\hline $\begin{array}{l}\text { CEM III/A } 32.5 \mathrm{~N} \text { with } \\
\text { GGBS }\end{array}$ & C7 & 2 & 6 & 11 & $0.45-0.61$ & 33 \\
\hline CEM III/B, unspecified* & W or FR & 3 & - & 3 & 0.50 & 3 \\
\hline CEM III/B $32.5 \mathrm{~N}$ & $\mathrm{C7}$ & 4 & - & 4 & $0.50-0.75$ & 7 \\
\hline
\end{tabular}

* No strength class given (ASTM or Australian standard). Based on the compressive strength of mortar five CEM I and one CEM II/B-S could be assigned to strength class $32.5 \mathrm{R}$ or $42.5 \mathrm{~N}$ [46 - 48, 52, 53, 55]. One CEM I was assigned to strength class $42.5 \mathrm{R}$ [38]. Two CEM II/B$\mathrm{S}$ and one CEM III/A were assigned to strength class $32.5 \mathrm{~N}$ [46]. Four cements (one CEM III/A and three CEM III/B) did not reach $32.5 \mathrm{~N} / \mathrm{mm}^{2}$ after 28 days and were neglected [46].

w/b: water / binder ratio $(b=$ cement content + SCM content $)$ 
Table A 4: Summary of the collected data on strength development of ternary blends containing GGBS and sFA

\begin{tabular}{|c|c|c|c|c|c|c|}
\hline binder & $\begin{array}{l}\text { storage } \\
\text { conditions }\end{array}$ & $\begin{array}{l}\text { number } \\
\text { of } \\
\text { cements }\end{array}$ & $\begin{array}{l}\text { number } \\
\text { of SCM }\end{array}$ & $\begin{array}{l}\text { number of } \\
\text { binder } \\
\text { combinations }\end{array}$ & $\begin{array}{l}\text { range of } \\
\text { w/b-ratio }\end{array}$ & $\begin{array}{l}\text { number of } \\
\text { concrete } \\
\text { mixes }\end{array}$ \\
\hline $\begin{array}{l}\text { CEM I } 42.5 \mathrm{R} \text { with GGBS } \\
\text { and SFA }\end{array}$ & $\mathrm{C} 7$ & 1 & $1 / 1^{*}$ & 1 & $0.42-0.51$ & 2 \\
\hline $\begin{array}{l}\text { CEM II/A-S } 52.5 \text { R with } \\
\text { sFA }\end{array}$ & $\mathrm{C} 7$ & 2 & 2 & 2 & $0.25 \quad 0.29$ & 2 \\
\hline $\begin{array}{l}\text { CEM II/B-S } 32.5 \text { R with } \\
\text { sFA }\end{array}$ & $\begin{array}{l}\text { W or FR } \\
\text { C7 }\end{array}$ & $\begin{array}{l}1 \\
2\end{array}$ & $\begin{array}{l}1 \\
5\end{array}$ & $\begin{array}{l}2 \\
5\end{array}$ & $\begin{array}{ll}0.44 & -0.52 \\
0.43 & -0.60\end{array}$ & $\begin{array}{l}2 \\
8\end{array}$ \\
\hline $\begin{array}{l}\text { CEM II/B-S 52.5 R with } \\
\text { sFA }\end{array}$ & $\mathrm{C7}$ & 1 & 1 & 1 & 0.25 & 1 \\
\hline $\begin{array}{l}\text { CEM II/B-S } 42.5 \mathrm{~N} \text { with } \\
\text { sFA }\end{array}$ & W or FR & 1 & 1 & 1 & $0.47-0.55$ & 2 \\
\hline $\begin{array}{l}\text { CEM II/B-S 32.5 R with } \\
\text { GGBS and sFA }\end{array}$ & $\mathrm{C} 7$ & 1 & $1 / 1^{*}$ & 1 & $0.42-0.51$ & 2 \\
\hline $\begin{array}{l}\text { CEM III/A } 32.5 \mathrm{~N} \text { with } \\
\text { sFA }\end{array}$ & $\begin{array}{l}\text { W or FR } \\
\text { C7 }\end{array}$ & $\begin{array}{l}2 \\
6\end{array}$ & $\begin{array}{l}2 \\
4\end{array}$ & $\begin{array}{c}2 \\
14\end{array}$ & $\begin{array}{ll}0.42 & -0.61 \\
0.42 & -0.65\end{array}$ & $\begin{array}{c}7 \\
39\end{array}$ \\
\hline $\begin{array}{l}\text { CEM III/A } 32.5 \mathrm{R} \text { with } \\
\text { sFA }\end{array}$ & $\begin{array}{c}\text { W or FR } \\
\mathrm{C} 7\end{array}$ & $\begin{array}{l}1 \\
1\end{array}$ & $\begin{array}{l}1 \\
3\end{array}$ & $\begin{array}{l}2 \\
6 \\
\end{array}$ & $\begin{array}{ll}0.45-0.67 \\
0.60-0.67\end{array}$ & $\begin{array}{l}7 \\
9 \\
\end{array}$ \\
\hline $\begin{array}{l}\text { CEM III/A } 42.5 \mathrm{~N} \text { with } \\
\text { sFA }\end{array}$ & $\mathrm{C} 7$ & 1 & 2 & 2 & $0.43-0.47$ & 5 \\
\hline $\begin{array}{l}\text { CEM III/A } 52.5 \mathrm{~N} \text { with } \\
\text { sFA }\end{array}$ & $\mathrm{C} 7$ & 1 & 1 & 1 & 0.32 & 1 \\
\hline $\begin{array}{l}\text { CEM III/B } 32.5 \mathrm{~N} \text { with } \\
\text { sFA }\end{array}$ & $\mathrm{C} 7$ & 3 & 4 & 8 & $0.47-0.67$ & 12 \\
\hline
\end{tabular}

* number GGBS / number sFA

$\mathrm{w} / \mathrm{b}: \quad$ water / binder ratio $(\mathrm{b}=$ cement content $+\mathrm{SCM}$ content $)$ 